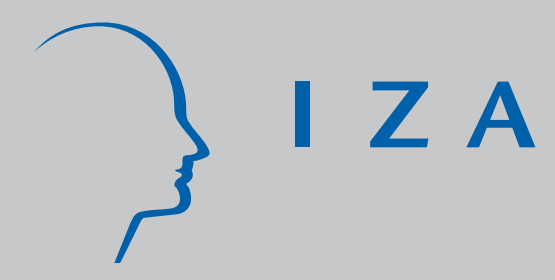

IZA DP No. 2342

Part-time Work and Occupational Attainment Amongst a Cohort of British Women

Victoria Prowse

September 2006 


\title{
Part-time Work and Occupational Attainment Amongst a Cohort of British Women
}

\author{
Victoria Prowse \\ Nuffield College, University of Oxford \\ and IZA Bonn
}

Discussion Paper No. 2342

September 2006

\author{
IZA \\ P.O. Box 7240 \\ 53072 Bonn \\ Germany \\ Phone: +49-228-3894-0 \\ Fax: +49-228-3894-180 \\ E-mail: iza@iza.org
}

Any opinions expressed here are those of the author(s) and not those of the institute. Research disseminated by IZA may include views on policy, but the institute itself takes no institutional policy positions.

The Institute for the Study of Labor (IZA) in Bonn is a local and virtual international research center and a place of communication between science, politics and business. IZA is an independent nonprofit company supported by Deutsche Post World Net. The center is associated with the University of Bonn and offers a stimulating research environment through its research networks, research support, and visitors and doctoral programs. IZA engages in (i) original and internationally competitive research in all fields of labor economics, (ii) development of policy concepts, and (iii) dissemination of research results and concepts to the interested public.

IZA Discussion Papers often represent preliminary work and are circulated to encourage discussion. Citation of such a paper should account for its provisional character. A revised version may be available directly from the author. 


\title{
ABSTRACT \\ Part-time Work and Occupational Attainment Amongst a Cohort of British Women*
}

\begin{abstract}
Using data on a cohort of British women who were born in 1958, this paper investigates the effects of qualifications, household structure and family background on the occupational penalty suffered by women in part-time employment. The analysis is conducted using a dynamic multinomial modelling framework in which hours of work and occupational attainment are jointly determined. The results reveal that at the bottom of the occupational hierarchy degree level qualifications improve the occupational attainment of women in parttime employment relative to that of women working full-time. In contrast, at top of the occupational hierarchy, degree level qualifications benefit full-timers more than part-timers. Contrary to the conventional wisdom, women with children have higher occupational attainment than childless women thus suggesting that women with children are relatively selective in terms of the jobs they are willing to accept. Furthermore, women with children experience a smaller part-time occupational penalty than childless women. Family background effects are present but small.
\end{abstract}

JEL Classification: $\quad \mathrm{C} 23, \mathrm{C} 25, \mathrm{~J} 62$

Keywords: occupational mobility, part-time employment

Corresponding author:

Victoria Prowse

Department of Economics

Manor Road Building

Manor Road

Oxford, OX1 3UQ

United Kingdom

E-mail: victoria.prowse@economics.ox.ac.uk

\footnotetext{
* I express my thanks for useful comments and discussion of this paper and earlier drafts to the following people: Alberto Behar; Steve Bond; David Gill; Kathryn Graddy; Valérie Lechene; Jim Malcomson; Alan Manning; and Bent Nielson. I have also benefited from discussions with participants at seminars in Oxford and at the 2006 EEA congress in Vienna. Any remaining errors are my own. This work has been supported by the ESRC, grant number PAT-030-2003-00229. This paper uses data from the National Child Development Survey. The relevant data sets are held at the UK Data Archive. See http://www. data-archive.ac.uk for further details.
} 


\section{Introduction}

This paper is concerned with the occupational attainment of British women in part-time employment. It is widely accepted that part-time jobs held by British women tend to be low quality jobs, concentrated in what are generally considered to be undesirable occupations such as catering and retail (see Grimshaw and Rubery, 2001; Manning and Petrongolo, 2005; Martin and Roberts, 1984; Rubery, 1998; Perry, 1988; Stewart and Greenhalgh, 1984). Furthermore, recent empirical evidence suggests that the part-time occupations gap is substantial. For example, based on a sample from the 2003-2004 UK Labour Force Survey, Manning and Petrongolo (2005) report that 46.2\% of women working full-time were employed in managerial, professional or technical occupations, whilst only $23.5 \%$ of women working part-time held jobs in one the these three occupational groups.

Many studies of women's occupational attainment which look at the effect of part-time work focus on establishing the existence of a part-time occupations gap after controlling for differences in the characteristics of women in full-time and part-time employment, referred to as composition effects (see, for example, Elliott et al., 2001; Jacobs, 1999; Manning and Petrongolo, 2005; Perry, 1988; Stewart and Greenhalgh, 1984). Abstracting from the issues surrounding the measurement of occupational attainment, these studies systematically find that women in part-time employment have significantly lower occupational attainment than full-time workers. However, the part-time occupations gap which remains after controlling for composition effects tends to be smaller than the total part-time occupations gap, thus confirming the presence of composition effects.

Instead of focusing of the existence of a part-time occupations gap, this study is primarily concerned with variation in the size of the part-time occupations gap according to individual characteristics. By taking this approach it is possible to determine how the occupational penalty that a woman experiences if she chooses to work part-time depends on her characteristics including her qualifications, household structure and family background. Thus, it is possible to establish whether qualifications improve the occupational attainment of women in part-time employment relative to that of women working full-time; if women from more privileged backgrounds escape the part-time occupational penalty; and, possibly most interestingly, whether women with children experience a larger part-time occupational penalty than childless women.

When interpreting the results of this analysis it is important to understand that variation in the part-time occupations gap according to individual characteristics is consistent with two different underlying processes (see Boskin, 1974; Schmidt and Strauss, 1975): (i) variation according to individual characteristics in the occupational opportunities available to full-time workers relative to those available to women in part-time employment; and (ii) variation according to individual characteristics and hours of work in women's preferences for jobs in particular occupations. Without placing further restrictions on the structure of preferences or making further assumptions about the nature 
of the full-time and part-time labor markets it is impossible to separate these two explanations.

Concerning the effects of some individual characteristics, it is undesirable to impose further structure on the problem. Consider, for example, the effect of qualifications on the part-time occupations gap. A part-time occupations gap which is larger amongst highly qualified women than amongst women with low levels of qualifications is consistent with both relatively favorable occupational opportunities for highly qualified women in full-time employment and a relatively high preference amongst women with low levels of qualifications in part-time employment for jobs in low occupations. It is therefore unappealing to exclude either variation in preferences or variation in opportunities according to qualifications. However, despite being unable to distinguish between these two explanations, determining how the part-time occupations gap varies with women's qualification is informative as it represents a first step towards understanding the effect of qualifications on the part-time occupations gap, and provides a basis for future research, possibly using detailed data on preferences or employers' policies to separate the effects of differences in preferences from the effects of differences in opportunities. Similar comments apply to the effect of family background on the part-time occupations gap.

Restrictions on the structure of preferences or opportunities are perhaps more appealing when interpreting the effects of other individual characteristics, For example, given a woman's choice of hours of work, it might be reasonable to assume that her occupational opportunities do not depend on the structure of her household. If this assumption holds then all variation in the part-time occupations gap according to household structure is due to variation in preferences. Consequently, if the occupational outcomes of women with children in part-time employment are found to be lower than those of childless women working part-time then one may accept the hypothesis that a proportion of the relatively low occupational attainment of women in part-time employment is due to a choice by women with children to hold part-time jobs in low occupations (for a further discussion of this possibility see Bonney, 2005; Hakim, 2000; Harris, 1993; Rubery et al., 1994). If, on the other hand, the occupational outcomes of women with children in part-time employment are not lower than those of childless women working part-time one may reject suggestions that women with children who are working part-time have lower occupational ambitions or are less committed to their careers than women without children, and seek alternative explanations for the low occupational attainment of women in part-time employment.

Using data on a cohort of British women who were born in 1958, this study adopts life-course perspective to analyzing women's occupational attainment between leaving full-time education and age 40 years. Women's occupational outcomes over this period are modelled using a dynamic multinomial modelling framework in which hours of work and occupational attainment are jointly determined. The modelling approach permits persistent unobserved differences between women in 
their unobserved productivity and preferences.

The results show that higher qualifications raise the occupational attainment of women in both full-time and part-time employment. Moreover, the part-time occupations gap varies according to the level of a woman's qualifications: a degree level qualification increases the part-time occupations gap at the top of the occupational hierarchy, whereas at the bottom of the occupational hierarchy the part-time occupations gap is smallest for women with degree level qualifications. Hence it is not systematically the case that women with higher qualifications are rewarded more in full-time employment than in part-time employment. In line with previous studies, children are found to cause women to withdraw from employment, and women with children who remain in employment are likely to move from full-time employment into part-time employment. The effect children on the occupational attainment of women who remain in employment is the opposite of what might be expected: conditional on being in either full-time or part-time employment women with children have, ceteris paribus, higher occupational attainment than childless women. This finding conflicts with the suggestion that women who use part-time jobs as a way of combining paid work with parenthood are less career focused than women in full-time employment. Instead, it appears instead that women with children are more selective in terms of the quality of jobs that they are willing to accept than childless women. This is particularly true of women working part-time and thus women with children experience a smaller part-time occupational penalty then childless women. Family background effects are present but small in magnitude. Specifically, there is weak evidence indicating that the part-time occupations gap is largest for women from privileged backgrounds.

This paper proceeds as follows. Section 2 introduces the National Child Development Survey (NCDS), the data source used in this application. This section also discusses the sample and the chosen measures of hours of work and occupational attainment. Section 3 contains a descriptive analysis of the occupational attainment and occupational dynamics of this cohort of women. The remainder of the paper is devoted to a formal econometric analysis of the employment and occupational outcomes of this cohort of women. Section 4 outlines the econometric model. Section 5 presents and discusses the results, and Section 6 concludes.

\section{NCDS Data and the Measurement of Occupational Attainment}

The empirical analysis undertaken in this paper is based on a sample of women taken from the NCDS. The NCDS is an ongoing cohort study which attempts to follow the lives of all those living in Great Britain who were born in the week commencing $3^{\text {rd }}$ March 1958. ${ }^{1}$ The initial survey consisted of 17419 children. To date, there have been six attempts to trace all members of this

\footnotetext{
${ }^{1}$ See O'Brien and Prescott-Clarke (1987), Prescott-Clarke et al. (1993) and Collins et al. (2001) for a complete description of the of the NCDS.
} 
birth cohort. These were undertaken in 1965 (age 7 years), 1969 (age 11 years), 1974 (age 16 years), 1981 (age 23 years), 1991 (age 33 years) and 1999-2000 (age 41-42 years ${ }^{2}$ ). In the first three of these follow-up surveys information was obtained from parents, schools and the cohort members themselves, while in the later surveys all information was collected directly from the cohort members themselves. Amongst other topics, the later surveys of the NCDS cover the employment and occupational outcomes of the cohort members, as well as the individuals' educational, fertility and relationship histories. In addition to the six main surveys, in 1978 contact was made with the schools attended by the cohort members at the time of the third follow-up in 1974. Schools were asked to detail of performance of the cohort members in any public examinations sat at the school. If the cohort member sat any examinations at a different school or at a Sixth-Form college or Further Education college these institutions were also contacted and asked to provide similar information.

The analysis below is based on an annual panel data set constructed primarily from data collected from the cohort members in the fifth and sixth follow-ups and from schools in 1978. The annual observations correspond to the women's characteristics, including employment and occupational outcomes, household structure, family background and qualifications on $1^{\text {st }}$ January each year. Each woman enters the panel in the January after leaving full-time education, and is observed annually up to and including January 1999, when the cohort members were age 40 years. In order to ensure the quality of the data several groups of women are excluded from the panel. The exclusions consist of women who did not respond to all relevant follow-ups of the survey, women for whom exam results in 1978 are missing, women who at any point during the survey reported themselves to be long-term sick or retired, and women who returned to full-time education. A total of 3394 women are in the final panel, corresponding to 80305 woman-year observations.

For the purpose of the empirical analysis it is necessary to distinguish a number of different labor market states corresponding to different hours of work and different occupational outcomes. The chosen measures of hours of work and occupational outcomes are constrained both by data availability and by the need for the variables to have a clear and meaningful interpretation. Regarding employment outcomes, the cohort members were asked to record the start and end dates of all jobs held between leaving full-time education and age 41-42 years. ${ }^{3}$ For each job, the cohort members were asked to record whether the job was full-time, defined as usual weekly hours of work of thirty or higher, or part-time, defined as usual weekly hours of work of between zero and thirty. The data on

\footnotetext{
${ }^{2}$ This follow-up was conducted between November 1999 and September 2000. The respondents were therefore either age 41 years or 42 years, depending on the date on which they were surveyed.

${ }^{3}$ Data on hours of work and occupational outcomes between leaving full-time education and age 33 years were collected in the fifth follow-up and data on hours of work and occupational outcomes between age 33 years and age 41-42 years were collected in the sixth follow-up. (Some data regarding labor market outcomes were also collected in the fourth follow-up when the cohort members were age 23 years. However the survey design is such such that these data are not readily comparable with those collected in the later follow-ups. Furthermore, the fifth and sixth follow-ups combined provide data on all labor market outcomes subsequent to leaving full-time education. Therefore it is not necessary to use the data on labor market outcomes which were collected in the fourth follow-up.)
} 
hours of work are therefore used to distinguish three states, namely full-time employment, part-time employment and non-employment. Actual hours of work were not recorded, and thus a continuous measure of hours of work is unavailable. For any period of non-employment the cohort members were asked to record the nature of their non-employment, for example, unemployment, family care, government training scheme or another reason. For the purpose of this study, no distinction is made between the different forms of non-employment. However it is useful to note that given this is a sample of women the vast majority of the non-employment consists of women engaged in family care.

The measurement of occupational attainment is far from straight forward. For the purpose of the current study it would be desirable to have a measure of occupational attainment summarizing the educational, training and experience requirements associated with a particular job. By and large, previous studies of occupational attainment have used either wage based or social class based measures of occupational attainment. Wage based measures of occupational attainment are usually operationalized by matching wage data to occupational groups and then ranking occupations on the basis of average pay (for applications see Connolly et al., 1992; Dolton and Makepeace, 1990; Greenhalgh and Stewart, 1985; Harper and Mohammad, 1997; Nickell, 1982). In contrast, social class based measures of occupational attainment allocate individual occupations to broad categories designed to group together similar occupations. If an ordered measure of occupational attainment is required the resulting occupational groups are ranked on the basis of required qualifications or training (studies using class based measures of occupational attainment include Blackwell, 2001; Jacobs, 1999; McRae, 1993; Schmidt and Strauss, 1975; Stewart and Greenhalgh, 1984).

Wage based measures of occupational attainment should partially reflect required education, training and experience. However, wages are also influenced by other factors including non-pecuniary job characteristics (Atrostic, 1982; Brown, 1980; Olson, 2002), the relative scarcity of relevant skills (Card and DiNardo, 2002; Moore and Ranjan, 2005), staff retention concerns (Akerlof and Yellen, 1990; Krueger and Summers, 1988; Shapiro and Stiglitz, 1984) and workplace unionization (Machin, 1997; Card, 1996). As such, wages may not entirely reflect occupational attainment as conceived in terms of competencies. Therefore, for the purpose of the analysis conducted in this study, a class based measure of occupational attainment is used.

For the sample in hand the social class of each job held by an individual was recorded according a classification known as "Social Class based on Occupation", henceforth referred to as Social Class. The Social Class of a job was derived from the job's occupational classification (classified according to the Standard Occupational Classification 1990 (SOC90)) and additional information concerning the nature of the woman's employment, including whether or not the job entailed managerial responsibilities and whether or not the individual was self-employed. ${ }^{4}$ There are six Social

\footnotetext{
${ }^{4}$ The SOC90 and the rules for defining Social Class groups are described in Volumes 1-3 of the Standard Occupational Classification (1990).
} 
Class groups: SC I (Professional, etc. occupations); SC II (Managerial and Technical occupations); SC IIIN (Skilled Non-manual occupations), SC IIIM (Skilled Manual occupations); SC IV (Partially Skilled occupations); and SC V (Unskilled occupations). ${ }^{5}$

For the purpose of the analysis undertaken in this paper some of the Social Class groups are amalgamated. Specifically, Social Class groups I and II are combined to form a single group consisting of professional, managerial and technical occupations. Social Class IIIN is unaltered, while Social Classes IIIM, IV and V are combined to form a single category consisting of all manual occupations. The resulting occupational groups are labelled higher non-manual occupations, lower non-manual occupations and manual occupations respectively. These amalgamations avoid having to separately consider the relatively small numbers of women in Social Class groups I and V, whilst still differentiating between the major levels of occupational attainment. Furthermore, these groupings avoid the slight ambiguity involved in differentiating between skilled manual and partially skilled manual occupations.

Combining the above defined measures of hours of work and occupational outcomes gives rise to seven labor market states: full-time employment in higher non-manual occupations (HNM-FT), lower non-manual occupations (LNM-FT), and manual occupations (M-FT); part-time employment in higher non-manual occupations (HNM-PT), lower non-manual occupations (LNM-PT), and manual occupations (M-PT); and non-employment (N-EMP).

\section{Employment Behavior and Occupational Attainment in the NCDS Cohort}

The descriptive analysis undertaken in this section seeks to introduce the reader to the main features of the sample and to document the extent of the part-time occupations gap amongst women in the NCDS cohort. The descriptive analysis also provides motivation for some aspects of the formal econometric analysis undertaken below. The first half of this section describes women's labor market outcomes for the period between leaving full-time education and age 40 years, and also details the changing pattern of women's transitions between labor market states over the same time horizon. Attention is then turned to differences between the occupational attainment of women in full-time and part-time employment.

Figure 1 shows the labor market outcomes of the sampled women between leaving full-time

\footnotetext{
${ }^{5}$ By using additional informational regarding the nature of individuals' employment, the Social Class groupings more accurately bring together individuals with similar levels of occupational skill than the SOC90 groupings. In most cases the SOC90 and the Social Class groupings classify jobs in a similar way. However, there are two substantial groups of workers who are classified differently. Firstly, persons with managerial duties are generally allocated to Social Class II irrespective of their SOC90 occupational group. Secondly, individuals working as self-employed managers or proprietors in service industry occupations, such a managers of restaurants and hairdressing salons, are allocated to Social Class IIIN, whereas the SOC90 allocates such individuals highest occupational group together with managers working in the upper echelons of business and the Civil Service.
} 


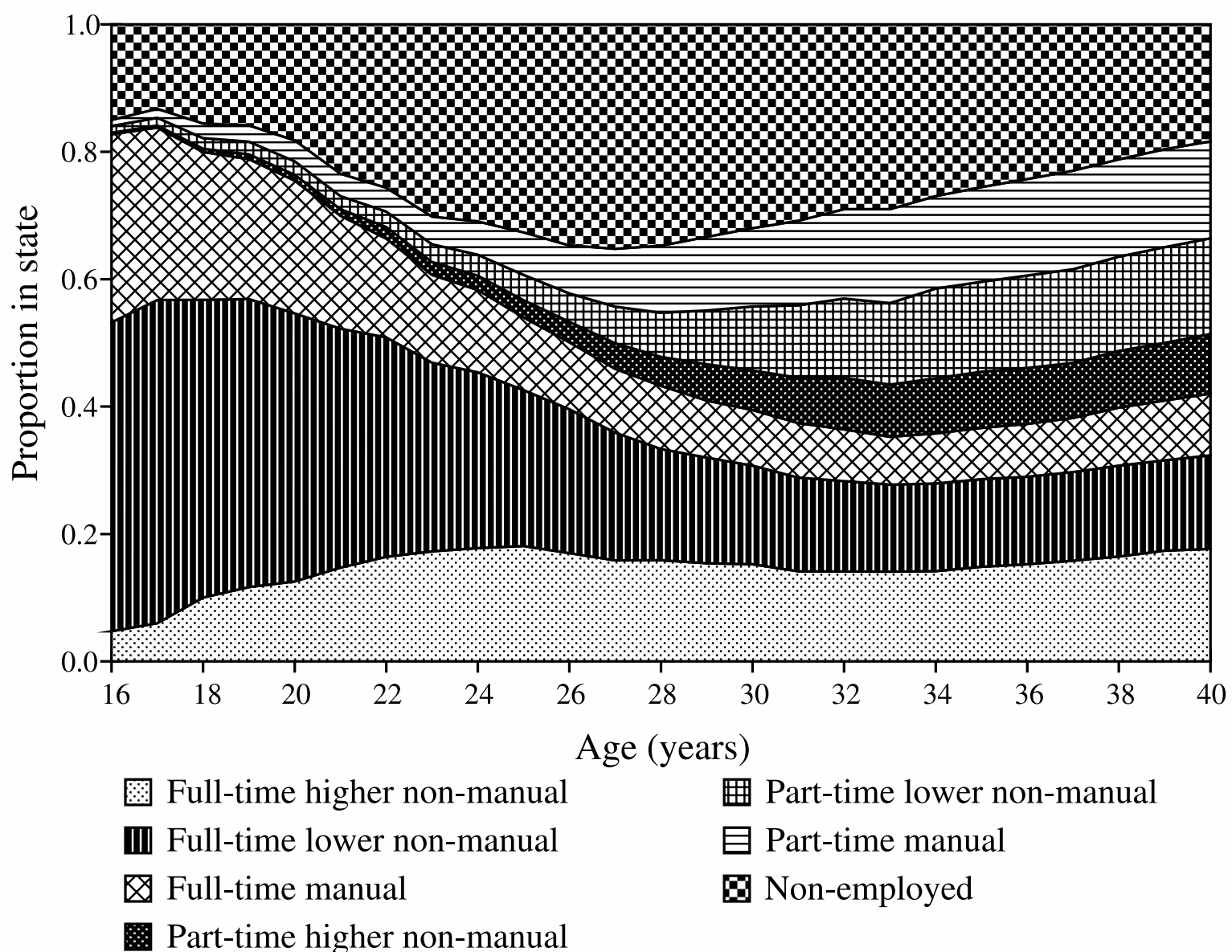

Figure 1: Labor market outcomes of women between leaving full-time education and age 40 years.

education and age 40 years. Over this period the proportion of women in non-employment displays a familiar hump-shaped profile, rising until age 28 years and falling thereafter. This trend is driven by women dropping out of employment around the time when they were caring for young children. The total proportion of women in part-time employment was increasing throughout the sample period, and between the ages of 24 and 32 years the proportion of women in part-time employment increased particularly quickly. Furthermore, the proportions of women in part-time employment in each of the three occupational categories: higher non-manual occupations; lower non-manual occupations; and manual occupations, were all increasing throughout the sample period. It is not possible to determine from this sample alone whether the rising prevalence of part-time employment amongst these women was due to life-cycle factors specific to this cohort of women or to a more widespread structural shift towards a higher level part-time employment. However, alternative United Kingdom data sources reveal that part-time became increasingly common over 1980s and 1990s. For example Lemaitre et al. (1997) report that part-time employment as a proportion of total employment rose from $19.0 \%$ in 1983 to $24.6 \%$ in 1996 . Therefore it appears that at least some of the increase in parttime employment observed in the NCDS cohort was due to an economy-wide increase in part-time employment. 


\begin{tabular}{|c|c|c|c|c|c|c|c|c|}
\hline \multicolumn{2}{|l|}{ 1975-1983 } & \multicolumn{7}{|c|}{ STATE IN YEAR $t+1$} \\
\hline \multirow{7}{*}{ STATE IN YEAR $t$} & HNM-FT & 86.38 & 3.95 & 2.13 & 1.03 & 0.21 & 0.71 & 5.58 \\
\hline & LNM-FT & 2.40 & 86.59 & 2.56 & 0.15 & 0.52 & 0.64 & 7.14 \\
\hline & M-FT & 2.44 & 4.26 & 81.38 & 0.15 & 0.35 & 1.63 & 9.79 \\
\hline & HNM-PT & 4.66 & 0.42 & 0.85 & 83.47 & 0.42 & 0.85 & 9.32 \\
\hline & LNM-PT & 2.20 & 5.29 & 1.10 & 0.66 & 76.87 & 3.96 & 9.91 \\
\hline & M-PT & 2.99 & 4.18 & 4.18 & 0.30 & 1.49 & 72.69 & 14.18 \\
\hline & N-EMP & 5.02 & 8.15 & 5.51 & 0.80 & 1.99 & 3.18 & 75.36 \\
\hline \multicolumn{2}{|l|}{ 1984-1992 } & \multicolumn{7}{|c|}{\begin{tabular}{|c|} 
STATE IN YEAR $t+1$ \\
HNM-FT LNM-FT M-FT HNM-PT HNM-PT M-PT N-EMP
\end{tabular}} \\
\hline \multirow{7}{*}{ STATE IN YEAR $t$} & HNM-FT & 86.32 & 1.91 & 1.09 & 2.01 & 0.53 & 0.60 & 7.54 \\
\hline & LNM-FT & 2.44 & 84.42 & 0.73 & 0.39 & 1.62 & 0.90 & 9.48 \\
\hline & M-FT & 2.35 & 1.82 & 81.31 & 0.56 & 1.06 & 3.41 & 9.49 \\
\hline & HNM-PT & 3.43 & 0.81 & 0.87 & 82.65 & 2.62 & 2.42 & 7.20 \\
\hline & LNM-PT & 1.41 & 2.39 & 0.88 & 1.28 & 80.16 & 3.99 & 9.90 \\
\hline & M-PT & 1.11 & 1.08 & 2.61 & 1.57 & 3.63 & 79.97 & 10.03 \\
\hline & N-EMP & 2.10 & 1.97 & 1.74 & 2.45 & 4.70 & 6.28 & 80.76 \\
\hline \multicolumn{2}{|l|}{ 1993-1999 } & \multicolumn{7}{|c|}{$\begin{array}{c}\text { STATE IN YEAR } t+1 \\
\text { HNM-FT LNM-FT M-FT HNM-PT HNM-PT }\end{array}$} \\
\hline \multirow{7}{*}{ STATE IN YEAR $t$} & HNM-FT & 94.79 & 0.71 & 0.46 & 1.36 & 0.33 & 0.25 & 2.10 \\
\hline & LNM-FT & 1.61 & 93.12 & 0.58 & 0.30 & 1.76 & 0.36 & 2.27 \\
\hline & M-FT & 1.00 & 1.05 & 92.12 & 0.35 & 1.15 & 1.76 & 2.56 \\
\hline & HNM-PT & 4.01 & 0.24 & 0.39 & 91.26 & 0.92 & 0.63 & 2.56 \\
\hline & LNM-PT & 1.41 & 2.89 & 0.88 & 0.74 & 89.48 & 1.80 & 2.80 \\
\hline & M-PT & 0.81 & 1.06 & 2.43 & 0.75 & 2.71 & 89.69 & 2.54 \\
\hline & N-EMP & 1.37 & 1.29 & 1.22 & 1.76 & 3.89 & 4.45 & 86.03 \\
\hline
\end{tabular}

Table 1: Average one year transition matrices for the years 1975-1983, 1984-1992 and 1993-1999. All figures are in percentage terms.

Amongst women who left full-time education at age 16 years over $80 \%$ were working full-time in the January immediately after leaving full-time eduction. These women were predominantly working in lower non-manual or manual occupations. The proportion of women in full-time employment decreased gradually over the first 20 years of the sample period and reached $34 \%$ when the women were aged 35 years. Over the same period the proportion of full-timers employed in higher nonmanual occupations increased, suggesting some degree of upwards occupational mobility for women in full-time employment. During the last six years of the sample the proportion of women working full-time increased slightly, presumably reflecting women returning to full-time employment as the demands posed by young children decreased.

Table 1 shows the average one year transitions matrices for the years 1975-1983, 1984-1992 and 1993-1999. These matrices were constructed by calculating a transition matrix each two year period between 1975 and 1999 and taking an appropriately weighted average over the relevant years. It is immediately evident from Table 1 that there was a high level of persistence in women's labor market outcomes. For example over the years 1975-1983 an average of $86 \%$ of women who were were working full-time in higher non-manual occupations one year were also working full-time in the same occupational group one year later. The level of persistence was higher for full-time jobs than for part-time jobs, and for both full-time and part-time jobs the level of persistence was, in general, 
increasing in the occupational status of the job.

Splitting the sample into three time periods reveals that the labor market dynamics of this cohort of women where non-stationary over the sample period. For all labor market states the level of persistence was higher at the end of the sample period than at the beginning. The largest increases in persistence were for part-time jobs in lower non-manual or manual occupations. This suggests that between the late 1970s and the late 1990s it became increasingly difficult for women to escape from low quality part-time jobs. What is more, for the period 1993-1999, transitions out of low quality part-time jobs were most frequently into low quality full-time jobs or non-employment; transitions into jobs in higher non-manual occupations, either full-time or part-time, were relatively uncommon. Consequently women who moved out of low quality part-time jobs during this period rarely experienced upwards occupational mobility. Consistent with the changing distribution of labor market outcomes shown in Figure 1, the patten of transitions between labor market states also changed markedly over the sample period: transitions into non-employment became less frequent, and transitions out of non-employment became increasingly likely to be into part-time employment rather than full-time employment.

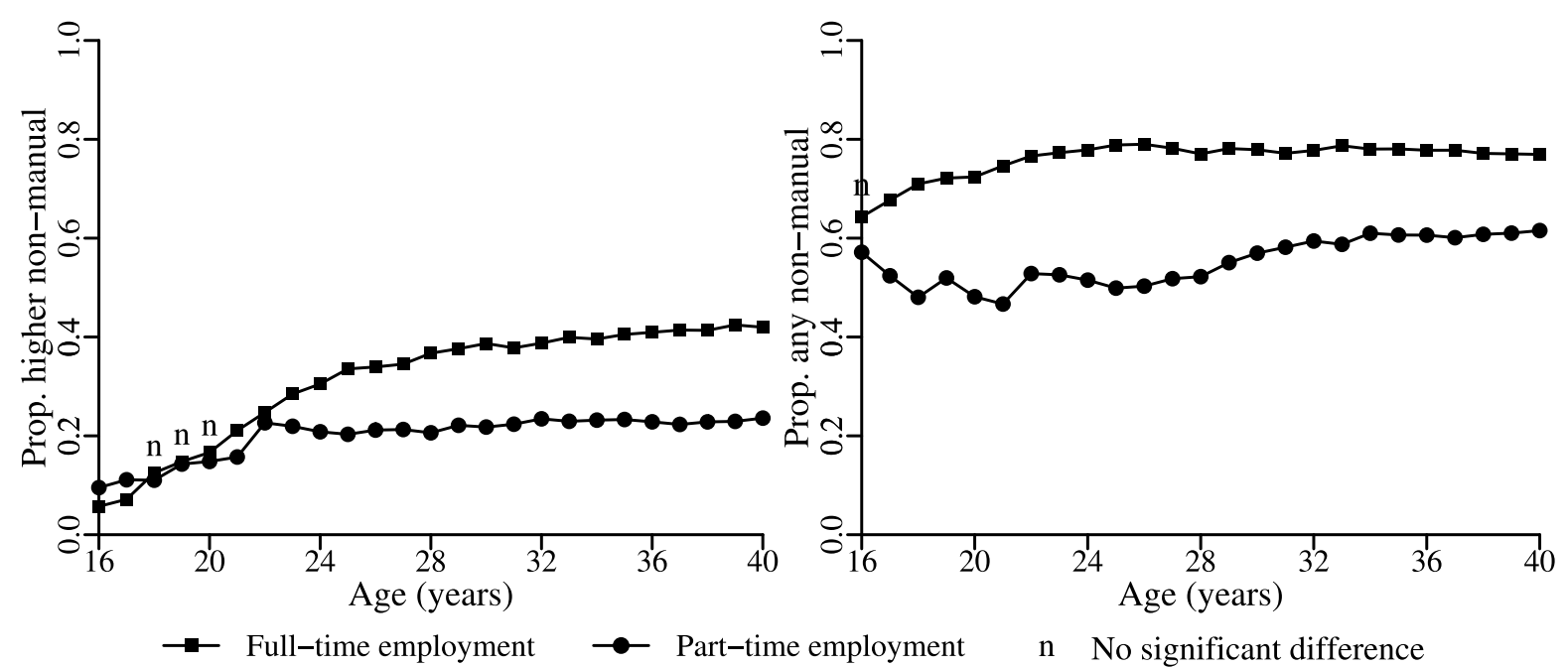

Figure 2: Proportion of full-timers and part-timers in higher non-manual occupations and all nonmanual occupations between leaving full-time education and age 40 years. Unless otherwise indicated the difference between the occupational attainment of women working full-time and women working part-time is significance at the $5 \%$ level.

Occupational attainment is measured in two ways: (i) the proportion of women working in higher non-manual occupations; and (ii) the proportion of women working in any non-manual occupation (i.e., any higher or lower non-manual occupation). Figure 2 compares the occupational attainment of women in full-time employment with that of women in part-time employment. The occupational attainment of full-time workers generally exceeded that of part-time workers. Indeed, from age seventeen years onwards, the proportion of part-timers working in non-manual occupations was significantly less than the proportion of full-timers working in non-manual occupations. Also, from 
age twenty-one years onwards, full-time workers were significantly more likely to be employed in higher non-manual occupations than part-time workers. Over the sample period there were two noticeable changes in the difference between the occupational attainment of full-time and part-time workers. Firstly, there was a slight narrowing of the gap between the proportions of full-timers and part-timers employed in non-manual occupations. This was due mainly to a steady increase in the proportion of part-time workers employed in non-manual occupations. Thus, according to this measure of occupational attainment, part-time workers improved their occupational status, both in absolute terms and relative to that of full-time workers, over the sample period. Secondly, the gap between the proportions of full-time and part-time workers employed in higher non-manual occupations widened substantially over the sample period: at age twenty years $14.8 \%$ of part-time workers where employed in higher non-manual occupations and $16.6 \%$ of full-time workers were employed in higher non-manual occupations. By age forty years the corresponding figures were $23.6 \%$ for part-time workers and $41.9 \%$ for full-time workers. It appears therefore that at the top of the occupational hierarchy the occupational attainment of women in full-time employment improved faster than that of women in part-time employment.

Taken together this descriptive analysis suggests a pattern of labor market outcomes and transitions that is broadly consistent with the changing life-cycle demands faced by this cohort of women over the sample period. The NCDS sample is also consistent with the rising prevalence of parttime employment experienced in the United Kingdom over the last two decades. Furthermore, the occupational outcomes observed amongst women in the NCDS cohort mirror those reported in related studies. In particular, the gap between the occupational attainment of full-time and parttime workers reported in, for example, Manning and Petrongolo (2005), Rubery (1998) and Stewart and Greenhalgh (1984) is clearly present in this NCDS sample. The formal econometric analysis presented in the reminder of this paper seeks to analyzes the difference between the occupational attainment of full-time and part-time workers more rigourously and in greater detail.

\section{Model}

Women's employment and occupational outcomes are modelled jointly in order to reflect that women choose between a range of different jobs corresponding to different hours of work, including zero, and different levels of occupational attainment; a woman's choice of hours of work is not made independently of her choice of occupation. Following Heckman (1978), Rosen (1972) and Schmidt and Strauss (1975) amongst others, each woman's observed sequence of labor market outcomes between leaving full-time education and age forty years is viewed as the solution to a lifetime utility maximization problem. Problems of this kind are sometimes analyzed using backwards recursion techniques (see, for example, Keane and Wolpin, 1997; Rust, 1996). However, the NCDS sample 
described above ends at age 40 years which is clearly well before the vast majority of women retire from the labor market. Thus backwards recursion can not be readily applied to this problem. The approach taken instead is to adopt a flexible empirical specification of women's labor market outcomes over time. This is interpreted as being descriptive of the exact solution to this problem.

The empirical specification takes the form of a dynamic mixed multinomial logit model of women's labor market outcomes. Every year each women choose one labor market state from the set seven available states, denoted $\mathcal{S}$, described above in Section 2. Woman $i$ 's payoff, net of any job search costs or fixed costs of employment, from choosing labor market state $j$ at time $t$ takes the following form

$$
U_{i, j, t}=\gamma_{j} X_{i, t}+\beta_{j} Z_{i, j, t}+\theta_{j} \alpha_{i}+\varepsilon_{i, j, t}, \text { for } i=1, \ldots, N ; j \in \mathcal{S} ; t=\tau_{i}, \ldots, T
$$

In the above $\tau_{i}$ denotes the year in which woman $i$ entered the sample, and $X_{i, t}$ and $Z_{i, j, t}$ are vectors of observed, possibly time varying, explanatory variables. The choice of variables to be included in $X_{i, t}$ and $Z_{i, j, t}$ is discussed immediately below. The remainder of this section then details the assumptions made about the error term in equation (1), $\theta_{j} \alpha_{i}+\varepsilon_{i, j, t}$, presents choice probabilities and outlines the estimation method.

The vector $Z_{i, j, t}$ consists of functions of woman $i$ 's past labor market outcomes. Specifically $Z_{i, j, t}$ includes a set of indicator variables detailing the woman's labor market state in the previous year and variables measuring the woman's experience in each labor market state. ${ }^{6}$ The inclusion of lagged dependent variables is intended to capture the high level persistence observed in women's labor market outcomes over the period of one year, while the experience terms allow for dependence in women's labor market outcomes over a longer time horizon. Hyslop (1999) provides a formal economic model which shows that jobs search costs can generate one-period, or Markovian, persistence in employment outcomes. Persistence over a longer time horizon may be due to firm specific human capital or training (Gritz, 1993; Krueger and Rouse, 1998), social capital associated with a particular workplace (Glaeser and Sacerdote, 2002; Woittiez and Kapteyn, 1998) or habit formation (Bover, 1991; Dynan, 2000; Kubin and Prinz, 2002). Motivated by the observation of non-stationarity in women's labor market dynamics (see Table 1) two additional, alternative specific, terms are included in $Z_{i, j, t}$. These take the form of an indicator of the woman being in labor market state $j$ at time $t-1$ interacted with a time trend and with a squared time trend. These alternative specific terms permit the coefficients on the own state lagged dependent variable to vary over time.

Mathematically, the specification of $\beta_{j} Z_{i, j, t}$ is as follows

$$
\beta_{j} Z_{i, j, t}=\sum_{\substack{k \in \mathcal{S} ; \\ k \neq \mathrm{N}-\mathrm{EMP}}} \check{\beta}_{j, k} Y_{i, k, t-1}+\tilde{\beta}_{j, 1} Y_{i, j, t-1} \mathrm{TIME}+\tilde{\beta}_{j, 2} Y_{i, j, t-1} \mathrm{TIME}^{2}+\sum_{\substack{k \in \mathcal{S} ; \\ k \neq \mathrm{N}-\mathrm{EMP}}} \ddot{\beta}_{j, k} \mathrm{EXP}_{i, k, t-1},
$$

\footnotetext{
${ }^{6}$ When conditioning on past labor market outcomes non-employment is always the omitted state.
} 
where $Y_{i, k, t-1}$ is an indicator variable taking the value one if woman $i$ was in labor market state $k$ at time $t-1$ and zero otherwise, TIME denotes a time trend, $\mathrm{EXP}_{i, k, t-1}$ is a variable measuring the number of years of experience the women has of working in labor market state $k$ up to and including time $t-1$. The first term on the right hand side of equation (2) represents the time invariant effect of a woman's labor market outcome at time $t-1$ on her payoff from choosing state $j$ at time $t$. The second and third terms in this equation denote the time varying effect of the woman being in labor market state $j$ at time $t-1$ on her payoff from remaining in this state. The last term in this equation represents the effect of labor market experience, differentiated by labor market state, on the woman's payoff of being in state $j$ at time $t .^{7}$

Any remaining observed variables which affect a woman's labor market outcomes enter the model through the vector $X_{i, t}$. In the empirical implementation below $X_{i, t}$ includes three variables detailing the woman's highest educational qualifications (no qualification or qualification below grade A-C O levels, grade A-C O levels, A levels, or degree level qualifications) ${ }^{8}$, an indicator of whether or not the woman's father was from a higher social class at the time of the woman's birth ${ }^{9}$, variables measuring the number of children living in the woman's household in each of three age categories (0-4 years, 5-11 years and 12-15 years), an indicator of whether or not the women is cohabiting, the cohabitation indicator interacted with the three child variables, and the log of the woman's partner's weekly net income expressed in year 1999 prices. $X_{i, t}$ also includes a time trend and a squared time trend, a cohort trend, which starts at one in the year the woman enters the labor market and increases by one each year, and a squared cohort trend. These trend variables are intended to capture any common macroeconomic or life-cycle effects. In order to recognize that a woman may engage in a period of job search or temporary employment between leaving full-time education and entering permanent employment, a variable indicating that the woman is in her first year in the labor market after leaving full-time education interacted with indicators of the woman's level of qualifications is also included. ${ }^{10}$

Several related studies have noted that fertility expectations may affect women's current labor market choices (see, for example, Cain and Dooley, 1976; Francesconi, 2002). In particular, women who plan to have children may be reluctant to acquire experience as they anticipate spending time out of the labor market in the future. A model accounting for women's fertility choices together

\footnotetext{
${ }^{7}$ More generally one could allow all of the coefficients on the lagged dependent variables to vary over time. However such a specification is likely to have poor numerical properties as only a small number of transitions are observed between for some pairs of labor market states.

${ }^{8} \mathrm{O}$ levels were typically taken at age 16 or 17 years. $61.6 \%$ of the women in this sample obtained at least one grade A-C O level. A levels were usually taken two years after O levels. $52.0 \%$ of the women in the sample obtained at least one A level. $9.6 \%$ of the sampled women obtained a degree level qualifications, the vast majority of whom graduated between the ages of 21 and 23 years.

${ }^{9} \mathrm{~A}$ higher social class is defined as any non-manual occupational group.

${ }^{10}$ The number of women whose highest qualification is an A level or a degree level qualification and who work parttime in their first year in the labor market is small. Thus a single variable is used to indicate the first year in the labor market for both of these groups of women.
} 
with employment and occupational outcomes is beyond the scope of this paper. However, in order to reflect the possible importance of fertility expectations to women's labor market decisions, two measures of fertility expectations are included in $X_{i, t}$. These are: (i) the number of children the woman had given birth to by age 40 years; and (ii) the woman's age when she gave birth to her first child.

The error term $\theta_{j} \alpha_{i}+\varepsilon_{i, j, t}$ includes all unobserved variables which affect woman $i$ 's labor market outcomes at time $t$. The persistent element of unobserved heterogeneity is represented by a single time invariant factor, denoted $\alpha_{i}$. The effect that the unobserved factor $\alpha_{i}$ has on woman $i$ 's payoff from being in labor market state $j$ is $\theta_{j} \alpha_{i}$ for $j \in \mathcal{S}$. Thus persistent unobserved heterogeneity enters the model in the same ways as observed individual characteristics. Persistent unobserved heterogeneity will arise from persistent differences between women in their unobserved productivity or unobserved elements of their preferences. Unobserved productivity may affect a woman's net payoff from being in a particular labor market state in a number of ways. Perhaps most obviously, productivity may affect the efficiency with which a woman is able to obtain job offers from particular sectors of the economy: if it is relatively easy for high productivity women to obtain jobs in high occupations $\theta_{\mathrm{HNM}-\mathrm{FT}}>\theta_{\mathrm{LNM}-\mathrm{FT}}>\theta_{\mathrm{M}-\mathrm{FT}}$ and $\theta_{\mathrm{HNM}-\mathrm{PT}}>\theta_{\mathrm{LNM}-\mathrm{PT}}>\theta_{\mathrm{M}-\mathrm{PT}}$. Alternatively, high productivity women may find it less onerous to hold jobs in high occupations, implying the same ordering of the $\theta \mathrm{s}$, or to work full-time rather than part-time, implying $\theta_{\mathrm{HNM}-\mathrm{FT}}>\theta_{\mathrm{HNM}-\mathrm{PT}}$, $\theta_{\text {LNM-FT }}>\theta_{\text {LNM-PT }}$ and $\theta_{\text {M-FT }}>\theta_{\text {M-PT }}$. Lastly, it is noted that if women's payoffs from employment relative to non-employment are increasing in their productivity then $\theta_{\mathrm{HNM}-\mathrm{FT}}, \ldots, \theta_{\mathrm{M}-\mathrm{PT}}$ should all be greater than $\theta_{\mathrm{N}-\mathrm{EMP}}$, implying that, ceteris paribus, the more productive a woman the more likely she is to choose employment over non-employment.

The second part of the error term in equation (1), $\varepsilon_{i, j, t}$, is assumed to be independent over $i$, $j$ and $t$ and to have a Type I Extreme Value distribution. These assumptions yield the following choice probabilities (see Nerlove and Press, 1973)

$$
\begin{aligned}
& P_{i, j, t}\left(Z_{i, j, t}, X_{i, t}, \alpha_{i} ; \Gamma, B, \Theta\right)= \frac{\exp \left(\gamma_{j} X_{i, t}+\beta_{j} Z_{i, j, t}+\theta_{j} \alpha_{i}\right)}{\sum_{k \in \mathcal{S}} \exp \left(\gamma_{k} X_{i, t}+\beta_{k} Z_{i, j, t}+\theta_{k} \alpha_{i}\right)}, \\
& \text { for } \quad i=1, \ldots, N ; j \in \mathcal{S} ; t=\tau_{i}, \ldots, T .
\end{aligned}
$$

In the above $\Gamma=\left[\gamma_{\mathrm{HNM}-\mathrm{FT}}, \ldots, \gamma_{\mathrm{N}-\mathrm{EMP}}\right], B=\left[\beta_{\mathrm{HNM}-\mathrm{FT}}, \ldots, \beta_{\mathrm{N}-\mathrm{EMP}}\right]$ and $\Theta=\left[\theta_{\mathrm{HNM}-\mathrm{FT}}, \ldots, \theta_{\mathrm{N}-\mathrm{EMP}}\right]$. If $\alpha_{i}$ were observed estimates of the parameters in equation (3) could be obtained by estimating a standard multinomial logit model. However, as $\alpha_{i}$ is taken to represent unobserved individual heterogeneity further assumptions must be made in order to estimate the parameters of the model. For the purpose of estimation, $\alpha_{i}$ is treated as a random effect meaning that $\alpha_{i}$ is assumed to be independent of all elements of $X_{i, t}$. It is further assumed that $\alpha_{i}$ is independent over the women in the sample. In a static context ignoring unobserved heterogeneity of this form leads only to 
an efficiency loss: parameter estimates remain consistent, and consistent standard errors can be obtained by taking account of the non-independent structure of the observations. In contrast, in a dynamic model, as is appropriate in the current application, ignoring persistent unobserved heterogeneity produces inconsistent parameter estimates (Heckman, 1981, discusses this issue in the context of a dynamic model of labor force participation). Intuitively, the inconsistency arises because $\alpha_{i}$ behaves like an omitted variable. Specifically, $Z_{i, j, t}$ includes past realizations of woman $i$ 's labor market outcomes which, by construction, were partly determined by $\alpha_{i}$. $\alpha_{i}$ also appears in the contemporaneous error term. Therefore the contemporaneous error term will be correlated with the explanatory variables represented by $Z_{i, j, t}$.

Following Heckman and Singer (1984), $\alpha_{i}$ is assumed to have a discrete distribution. According to this specification each woman is one of a finite number of different types, where each type of woman has different persistent unobserved characteristics. For the analysis below the model is estimated assuming that the distribution of $\alpha_{i}$ has three distinct mass points. The mass points are located at unknown positions $\alpha^{1}, \alpha^{2}, \alpha^{3}$. Without loss of generality the mass points are assumed to be ordered with $\alpha^{1}<\alpha^{2}<\alpha^{3}$. The probability with which woman $i$ has $\alpha_{i}=\alpha^{r}$ is $\pi^{r}$, where $\pi^{r}>0$ for all $r$ and $\sum_{r=1,2,3} \pi^{r}=1$. The positions of the mass points and their associated probabilities are estimated jointly with the other parameters of the model. The motivation for choosing three mass points to describe distribution for the random effect $\alpha_{i}$ is outlined in Appendix IV.

Before proceeding to estimate this model two sets of identifying normalizations must be imposed. The first set of normalizations are scale normalizations and are common to all multinomial logit models. Examining equation (3) it is clear that multiplying any element of each of the parameter vectors $\gamma_{j}$ for $j \in \mathcal{S}$ by any common positive constant leaves all of the choice probabilities unaltered. The same is true of $\theta_{j}$ for $j \in \mathcal{S}$. Similarly, multiplying all of the coefficients on any element of $Z_{i, j, t}$ which does not vary across alternatives by any common positive constant again leaves all of the choice probabilities unaltered. Therefore, $\gamma_{\mathrm{N}-\mathrm{EMP}}, \theta_{\mathrm{N}-\mathrm{EMP}}$ and $\check{\beta}_{\mathrm{N}-\mathrm{EMP}, k}$ and $\ddot{\beta}_{\mathrm{N}-\mathrm{EMP}, k}$ for $k \in \mathcal{S}, k \neq \mathrm{N}$-EMP are all normalized to zero.

The second set of normalizations concern the random effect $\alpha_{i}$ and its associated coefficients. Note that any proportional increase in the random effect can be perfectly offset by appropriate adjustments of the coefficients $\theta_{j}$ for $j \in \mathcal{S}, j \neq \mathrm{N}$-EMP. This implies that the scale of the random effect is not identified separately from the scale of the $\theta$ parameters. To counter this problem $\theta_{\text {HNM-FT }}$ is normalized to one. ${ }^{11}$ Furthermore, a location normalization must be imposed on the random effect as shifting the location of each of the three values of $\alpha_{i}$ by the same amount and adjusting the alternative specific intercepts appropriately leaves the model unaltered. Thus, without loss of generality, the lowest value of $\alpha_{i}$ is normalized to zero.

\footnotetext{
${ }^{11}$ In order for this normalization to be effective the true value of $\theta_{\text {HNM-FT }}$ must be non-zero.
} 
Parameter estimates are obtained by exact maximum likelihood estimation. Conditional on $\alpha_{i}$ woman $i$ 's choice probabilities are independent over time. It follows that woman $i$ 's likelihood contribution conditional on $\alpha_{i}$ is

$$
\mathcal{L}_{i}\left(\Gamma, B, \Theta ; \alpha_{i}, Z_{i, j, t}, X_{i, t}\right)=\prod_{t=\tau_{i}, \ldots, T} \prod_{k \in \mathcal{S}} P_{i, k, t}\left(Z_{i, j, t}, X_{i, t}, \alpha_{i} ; \Gamma, B, \Theta\right)^{Y_{i, k, t}}
$$

Given the above assumptions regarding the distribution of $\alpha_{i}$, woman $i$ 's marginal likelihood contribution is found by taking an appropriately weighted sum of equation (4). Thus

$$
\mathcal{L}_{i}\left(\Gamma, B, \Theta, A ; Z_{i, j, t}, X_{i, t}\right)=\sum_{r=1,2,3}\left[\pi_{r} \prod_{t=\tau_{i}, \ldots, T} \prod_{k \in \mathcal{S}} P_{i, k, t}\left(Z_{i, j, t}, X_{i, t}, \alpha^{r} ; \Gamma, B, \Theta\right)^{Y_{i, k, t}}\right],
$$

where $A$ denotes the parameters describing the distribution of the random effect $\alpha_{i}$. The log likelihood function for the sample is found by taking the sum of the individual log likelihood contributions. Parameter estimates are found by maximizing the log likelihood function using a BFGS quasi-Newton Raphson algorithm which utilizes analytic derivatives for all of the parameters. Asymptotic standard errors are obtained from the inverse hessian.

\section{Results}

Estimates of the parameters of the dynamic mixed multinomial logit model with persistent unobserved heterogeneity are detailed in Tables 2 and 3. Before discussing the results, goodness of fit analysis is conducted in order to establish the validity of the model. Next, the effects of persistent unobserved heterogeneity, qualifications, family background and household structure on women's occupational attainment and the part-time occupations gap are reported. When discussing the effect of persistent unobserved heterogeneity, the practical implications of ignoring persistent unobservables are outlined.

\subsection{Goodness of Fit}

The results are meaningful only if the model is able to explain the principal features of the sample. Two approaches are taken to assessing the fit of the model. Both approaches are based the output of a simulation which uses the parameter estimates to generate a sequence of employment and occupational outcomes for each woman in the sample. ${ }^{12}$ The first method used to assess the fit of the model consists of comparing the simulated proportion of women in each labor market state in each year with the corresponding proportion observed in the sample. Table 5 in Appendix II shows that the model accurately predicts the observed proportion of women in each labor market state in each year. The only slight difference between the observed and simulated proportions is

\footnotetext{
${ }^{12}$ The design of this simulation is described in Appendix I.
} 


\begin{tabular}{|c|c|c|c|c|c|c|c|}
\hline & HNM-FT & LNM-FT & M-FT & HNM-PT & LNM-PT & M-PT & N-EMP \\
\hline $\mathrm{HNM} \mathrm{FT}_{t-1}$ & $\begin{array}{l}5.288^{* *} \\
(0.26)\end{array}$ & $\begin{array}{l}1.37^{* *} \\
(0.18)\end{array}$ & $\begin{array}{l}1.27^{* *} \\
(0.20)\end{array}$ & $\begin{array}{l}1.16^{* *} \\
(0.20)\end{array}$ & $\begin{array}{r}-0.09 \\
(0.25)\end{array}$ & $\begin{array}{l}0.16 \\
(0.22)\end{array}$ & \\
\hline $\mathrm{LNM}_{-\mathrm{FT}_{t-1}}$ & $\stackrel{1.51}{ }_{(0.17)}^{* *}$ & $\begin{array}{l}3.35 \\
(0.18)\end{array}$ & $\stackrel{1}{(0.16)}^{* *}$ & $\begin{array}{l}0.31 \\
(0.24)\end{array}$ & $\begin{array}{l}0.49^{* *} \\
(0.18)\end{array}$ & $\begin{array}{l}0.12 \\
(0.19)\end{array}$ & \\
\hline $\mathrm{M}-\mathrm{FT}_{t-1}$ & $\stackrel{1.34}{(0.18)}^{* *}$ & $\begin{array}{l}1.07^{* *} \\
(0.16)\end{array}$ & $\begin{array}{l}3.49^{* *} \\
(0.19)\end{array}$ & $\begin{array}{l}0.33 \\
(0.27)\end{array}$ & $\begin{array}{l}0.28 \\
(0.21)\end{array}$ & $\begin{array}{l}0.91 \\
(0.17)\end{array}$ & \\
\hline $\mathrm{HNM} \mathrm{PT}_{t-1}$ & $\underbrace{1.72}_{(0.23)}{ }^{* *}$ & $\begin{array}{l}0.17 \\
(0.34)\end{array}$ & $\begin{array}{l}0.81 * * \\
(0.33)\end{array}$ & $\begin{array}{l}8.64 \\
(0.59)\end{array}$ & $\begin{array}{l}0.77^{* *} \\
(0.25)\end{array}$ & $\begin{array}{l}0.68^{* *} \\
(0.26)\end{array}$ & \\
\hline $\mathrm{LNM}_{-} \mathrm{PT}_{t-1}$ & $\begin{array}{l}0.99^{* *} \\
(0.23)^{*}\end{array}$ & $l_{(0.21)}^{1.30}$ & $\begin{array}{l}0.79^{* *} \\
(0.26)\end{array}$ & $\begin{array}{l}0.68^{* *} \\
(0.25)^{*}\end{array}$ & $\begin{array}{l}6.60^{* *} \\
(0.33)^{*}\end{array}$ & $\begin{array}{l}0.93 \\
(0.20)\end{array}$ & \\
\hline $\mathrm{M}-\mathrm{PT}_{t-1}$ & $\begin{array}{l}0.80 \\
(0.22)\end{array}$ & $\begin{array}{l}0.63^{* *} \\
(0.21)\end{array}$ & $\begin{array}{l}1.59^{* *} \\
(0.19)\end{array}$ & $\underbrace{1.14}_{(0.23)}$ & ${ }_{(0.20)}{ }^{* *}$ & $\begin{array}{l}5.13 \\
(0.29)\end{array}$ & \\
\hline OWN STATE $_{t-1} \times$ TIME & $\begin{array}{l}-0.15^{* *} \\
(0.03)\end{array}$ & $\begin{array}{l}0.12 \\
(0.03)\end{array}$ & $\begin{array}{l}0.15^{* *} \\
(0.03)\end{array}$ & $\begin{array}{l}-0.49^{* *} \\
(0.07)\end{array}$ & $\begin{array}{l}-0.30^{* *} \\
(0.04)\end{array}$ & $\begin{array}{l}-0.18^{* *} \\
(0.04)\end{array}$ & $\begin{array}{l}-0.07^{* *} \\
(0.02)\end{array}$ \\
\hline OWN STATE $_{t-1} \times \operatorname{TIME}^{2} / 100$ & $\begin{array}{l}0.68 \\
(0.12)\end{array}$ & $\begin{array}{c}-0.19 * \\
(0.10)\end{array}$ & $\begin{array}{c}-0.35^{* *} \\
(0.11)\end{array}$ & $\begin{array}{l}1.37 \text { ** } \\
(0.23)\end{array}$ & $\begin{array}{l}0.80 \\
(0.14)\end{array}$ & $\begin{array}{l}0.64 \\
(0.12)\end{array}$ & $\begin{array}{l}0.65 \text { ** } \\
(0.08)\end{array}$ \\
\hline EXP-HNM-FT & $\begin{array}{r}-0.03 \\
(0.02)\end{array}$ & $\begin{array}{c}-0.12 \text { ** } \\
(0.02)\end{array}$ & $\begin{array}{c}-0.11 \\
(0.02)\end{array}$ & $\begin{array}{r}-0.01 \\
(0.03)\end{array}$ & $\begin{array}{c}-0.10^{* *} \\
(0.02)\end{array}$ & $\begin{array}{c}-0.14^{* *} \\
(0.02)\end{array}$ & \\
\hline EXP-LNM-FT & $\begin{array}{c}-0.11^{* *} \\
(0.02)\end{array}$ & $\begin{array}{r}-0.01 \\
(0.01)\end{array}$ & $\begin{array}{c}-0.12^{* *} \\
(0.02)\end{array}$ & $\begin{array}{c}-0.12^{* *} \\
(0.03)\end{array}$ & $\begin{array}{r}-0.02 \\
(0.02)\end{array}$ & $\begin{array}{c}-0.10^{* *} \\
(0.02)\end{array}$ & \\
\hline EXP-M-FT & $\begin{array}{c}-0.11^{* *} \\
(0.02)\end{array}$ & $\begin{array}{c}-0.09^{* *} \\
(0.02)\end{array}$ & $\begin{array}{r}-0.02 \\
(0.02)\end{array}$ & $\begin{array}{c}-0.10^{* *} \\
(0.03)\end{array}$ & $\begin{array}{c}-0.06^{* *} \\
(0.02)\end{array}$ & $\begin{array}{c}-0.06^{* *} \\
(0.02)\end{array}$ & \\
\hline EXP-HNM-PT & $\begin{array}{c}0.04 \\
(0.03)\end{array}$ & $\begin{array}{r}-0.02 \\
(0.04)\end{array}$ & $\begin{array}{r}-0.06 \\
(0.04)\end{array}$ & $\begin{array}{l}0.11 \\
(0.03)\end{array}$ & $\begin{array}{r}-0.03 \\
(0.03)\end{array}$ & $\begin{array}{c}-0.08^{*} \\
(0.04)\end{array}$ & \\
\hline EXP-LNM-PT & $\begin{array}{r}-0.02 \\
(0.03)\end{array}$ & $\begin{array}{l}0.05 \\
(0.02)\end{array}$ & $\begin{array}{r}-0.03 \\
(0.03)\end{array}$ & $\begin{array}{l}0.02 \\
(0.03)\end{array}$ & $\begin{array}{l}0.099^{* *} \\
(0.02)\end{array}$ & $\begin{array}{r}-0.03 \\
(0.02)\end{array}$ & \\
\hline EXP-M-PT & $\begin{array}{c}-0.05^{*} \\
(0.03)\end{array}$ & $\begin{array}{l}0.01 \\
(0.02)\end{array}$ & $\begin{array}{r}-0.02 \\
(0.02)\end{array}$ & $\begin{array}{c}-0.07^{* *} \\
(0.03)\end{array}$ & $\begin{array}{r}-0.01 \\
(0.02)\end{array}$ & $\begin{array}{c}0.00 \\
(0.02)\end{array}$ & \\
\hline O LEVELS & $\begin{array}{l}0.47^{* *} \\
(0.07)\end{array}$ & $\begin{array}{l}0.41^{* *} \\
(0.06)\end{array}$ & $\begin{array}{r}-0.04 \\
(0.06)\end{array}$ & $\begin{array}{l}0.49^{* *} \\
(0.09)\end{array}$ & $\begin{array}{l}0.37^{* *} \\
(0.07)\end{array}$ & $\begin{array}{l}0.03 \\
(0.06)\end{array}$ & \\
\hline A LEVELS & $\begin{array}{l}0.62 \text { ** } \\
(0.13)\end{array}$ & $\begin{array}{l}0.51 \text { ** } \\
(0.11)\end{array}$ & $\begin{array}{c}-0.33^{* *} \\
(0.13)\end{array}$ & $\begin{array}{l}0.48^{* *} \\
(0.16)\end{array}$ & $\begin{array}{l}0.41 \\
(0.12)\end{array}$ & $\begin{array}{r}-0.20 \\
(0.14)\end{array}$ & \\
\hline DEGREE & $\begin{array}{l}0.76 \\
(0.18)\end{array}$ & $\begin{array}{l}0.42 \\
(0.19)\end{array}$ ** & $\begin{array}{l}0.05 \\
(0.19)\end{array}$ & $\begin{array}{l}0.56^{* *} \\
(0.21)\end{array}$ & $\underset{(0.20)}{0.41}{ }^{*}$ & $\begin{array}{r}-0.16 \\
(0.21)\end{array}$ & \\
\hline FATHER'S SOCIAL CLASS & $\begin{array}{r}-0.07 \\
(0.07)\end{array}$ & $\begin{array}{r}-0.08 \\
(0.06)\end{array}$ & $\begin{array}{c}-0.21 \\
(0.06)\end{array}$ & $\begin{array}{l}0.17^{*} \\
(0.08)\end{array}$ & $\begin{array}{c}-0.05 \\
(0.06)\end{array}$ & $\begin{array}{r}-0.06 \\
(0.06)\end{array}$ & \\
\hline CHILD04 & $\begin{array}{c}-1.72^{* *} \\
(0.19)\end{array}$ & $\begin{array}{c}-1.86^{* *} \\
(0.16)\end{array}$ & $\begin{array}{c}-1.65^{* *} \\
(0.16)\end{array}$ & $\begin{array}{r}-0.42 \\
(0.29)\end{array}$ & $\begin{array}{c}-0.39 * \\
(0.19)\end{array}$ & $\begin{array}{c}-0.40^{* *} \\
(0.12)\end{array}$ & \\
\hline CHILD511 & $\begin{array}{c}-0.85^{* *} \\
(0.15)\end{array}$ & $\begin{array}{c}-0.67^{* *} \\
(0.11)\end{array}$ & $\begin{array}{c}-0.68^{* *} \\
(0.12)\end{array}$ & $\begin{array}{r}-0.26 \\
(0.20)\end{array}$ & $\begin{array}{c}-0.26^{* *} \\
(0.12)\end{array}$ & $\begin{array}{r}-0.02 \\
(0.09)\end{array}$ & \\
\hline CHILD1215 & $\begin{array}{r}-0.24 \\
(0.21)\end{array}$ & $\begin{array}{r}-0.27 \\
(0.23)\end{array}$ & $\begin{array}{r}-0.36 \\
(0.20)\end{array}$ & $\begin{array}{r}-0.75 \\
(0.59)\end{array}$ & $\begin{array}{c}-0.11 \\
(0.20)\end{array}$ & $\begin{array}{c}-0.11 \\
(0.15)\end{array}$ & \\
\hline COHABIT & $\begin{array}{c}-0.99 * * \\
(0.08)\end{array}$ & $\begin{array}{c}-0.80^{* *} \\
(0.07)\end{array}$ & $\begin{array}{c}-0.89 * * \\
(0.08)\end{array}$ & $\begin{array}{c}-0.32 * \\
(0.15)\end{array}$ & $\begin{array}{c}-0.23 \text { ** } \\
(0.11)\end{array}$ & $\begin{array}{c}-0.44^{* *} \\
(0.09)\end{array}$ & \\
\hline COHABIT $\times$ CHILD04 & $\begin{array}{c}0.23 \\
(0.20)\end{array}$ & $\begin{array}{r}-0.06 \\
(0.17)\end{array}$ & $\begin{array}{l}0.52 \\
(0.16)\end{array}$ & $\begin{array}{l}0.07 \\
(0.29)\end{array}$ & $\begin{array}{c}0.03 \\
(0.20)\end{array}$ & $\begin{array}{l}0.15 \\
(0.13)\end{array}$ & \\
\hline COHABIT $\times$ CHILD511 & $\begin{array}{l}0.77^{* *} \\
(0.15)\end{array}$ & $\begin{array}{l}0.511^{* *} \\
(0.11)\end{array}$ & $\begin{array}{l}0.66^{* *} \\
(0.12)\end{array}$ & $\begin{array}{l}0.36 \\
(0.20)\end{array}$ & $\begin{array}{l}0.49^{* *} \\
(0.11)\end{array}$ & $\begin{array}{l}0.355^{* *} \\
(0.09)\end{array}$ & \\
\hline COHABIT $\times$ CHILD 1215 & $\begin{array}{l}0.40 \\
(0.22)\end{array}$ & $\begin{array}{l}0.44 \\
(0.23)\end{array}$ & $\begin{array}{l}0.43^{* *} \\
(0.20)\end{array}$ & $\begin{array}{c}0.79 \\
(0.59)\end{array}$ & $\begin{array}{c}0.24 \\
(0.20)\end{array}$ & $\begin{array}{l}0.22 \\
(0.16)\end{array}$ & \\
\hline \# OF CHILDREN BY 40 & $\begin{array}{c}-0.31^{* *} \\
(0.04)\end{array}$ & $\begin{array}{c}-0.30^{* *} \\
(0.03)\end{array}$ & $\begin{array}{c}-0.21^{* *} \\
(0.03)\end{array}$ & $\begin{array}{c}-0.18^{* *} \\
(0.06)\end{array}$ & $\begin{array}{c}-0.37^{* *} \\
(0.04)\end{array}$ & $\begin{array}{c}-0.311^{* *} \\
(0.04)\end{array}$ & \\
\hline AGE AT FIRST CHILD/10 & ${ }_{(0.03)}^{0.14}{ }^{* *}$ & $\begin{array}{l}0.12 \\
(0.03)\end{array}$ & $\begin{array}{c}0.04 \\
(0.03)\end{array}$ & $\begin{array}{l}0.19 \\
(0.04)\end{array}$ & $\begin{array}{l}0.21 \\
(0.03)\end{array}$ & $\begin{array}{l}0.11 \\
(0.03)\end{array}$ & \\
\hline LOG (PARTNERS PAY/100) & $\begin{array}{r}-0.04 \\
(0.04)\end{array}$ & $\begin{array}{r}-0.03 \\
(0.03)\end{array}$ & $\begin{array}{c}-0.09 * \\
(0.04)\end{array}$ & $\begin{array}{r}-0.03 \\
(0.05)\end{array}$ & $\begin{array}{r}-0.05 \\
(0.04)\end{array}$ & $\begin{array}{c}-0.10^{* *} \\
(0.03)\end{array}$ & \\
\hline INTERCEPT & $\begin{array}{c}-3.59^{* *} \\
(0.22)\end{array}$ & $\begin{array}{c}-1.25^{* *} \\
(0.17) \\
\end{array}$ & $\begin{array}{c}-1.27^{* *} \\
(0.18) \\
\end{array}$ & $\begin{array}{l}-6.92^{* *} \\
(0.39) \\
\end{array}$ & $\begin{array}{l}-4.79^{* *} \\
(0.28) \\
\end{array}$ & $\begin{array}{l}-3.40^{* *} \\
(0.24) \\
\end{array}$ & \\
\hline \multicolumn{8}{|c|}{ RANDOM EFFECT PARAMETERS } \\
\hline $\operatorname{PROB}\left(\alpha_{i}=\alpha^{1}\right)$ & $\begin{array}{l}0.13^{* *} \\
(0.02)\end{array}$ & $\alpha^{1}$ & $\underline{0}$ & \multicolumn{2}{|c|}{$\theta_{\text {LNM-FT }}$} & $\begin{array}{l}0.84^{* *} \\
(0.05)\end{array}$ & \\
\hline $\operatorname{PROB}\left(\alpha_{i}=\alpha^{2}\right)$ & $\begin{array}{l}0.622^{* *} \\
(0.03)\end{array}$ & $\alpha^{2}$ & $\begin{array}{l}2.08^{* *} \\
(0.11)\end{array}$ & \multicolumn{2}{|c|}{$\theta_{\mathrm{M}-\mathrm{FT}}$} & $\begin{array}{l}0.74^{* *} \\
(0.06)\end{array}$ & \\
\hline \multirow[t]{3}{*}{$\operatorname{PROB}\left(\alpha_{i}=\alpha^{3}\right)$} & $\begin{array}{l}0.25 \\
(0.01)\end{array}$ & $\alpha^{3}$ & $\begin{array}{l}4.39^{* *} \\
(0.20)\end{array}$ & \multicolumn{2}{|c|}{$\theta_{\mathrm{HNM}-\mathrm{PT}}$} & $\begin{array}{l}0.80 \\
(0.10)\end{array}$ & \\
\hline & & & & \multicolumn{2}{|c|}{$\theta_{\text {LNM-PT }}$} & $\begin{array}{l}0.711^{* *} \\
(0.08)\end{array}$ & \\
\hline & & & & \multicolumn{2}{|c|}{$\theta_{\mathrm{M}-\mathrm{PT}}$} & $\begin{array}{l}0.67^{* *} \\
(0.07)\end{array}$ & \\
\hline
\end{tabular}

NOTES: McFadden's Pseudo $\mathrm{R}^{2}=1$-Restricted $\quad$ Log $\quad$ Likelhood/Unrestrcited $\quad$ Log $\quad$ Likelihood; $\quad$ BIC=-2Log Likelihood $+\ln (N T)$ Parameters.

Table 2: Parameter estimates for dynamic mixed multinomial logit model of labor market outcomes model with persistent unobserved heterogeneity represented by three mass points. The model also includes time trends, year of entry trends, and controls for first year in the labor market interacted with level of qualifications (see Table 3). Standard errors in parenthesis. ${ }^{*}$ indicates significance at the $5 \%$ level and ${ }^{* *}$ indicates significance at the $1 \%$ level. 


\begin{tabular}{|c|c|c|c|c|c|c|}
\hline & HNM-FT & LNM-FT & M-FT & HNM-PT & LNM-PT & M-PT \\
\hline YEAR OF ENTRY TREND & $\begin{array}{c}-0.18^{* *} \\
(0.20)\end{array}$ & $\begin{array}{l}0.12 \\
(0.14)\end{array}$ & $\begin{array}{l}0.08^{* *} \\
(0.15)\end{array}$ & $\begin{array}{c}-0.08^{* *} \\
(0.70)\end{array}$ & $\begin{array}{l}0.19{ }^{* *} \\
(0.35)\end{array}$ & $\begin{array}{l}0.28^{* *} \\
(0.31)\end{array}$ \\
\hline YEAR OF ENTRY TREND $/ 100$ & 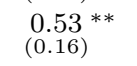 & $\begin{array}{c}-0.23^{* *} \\
(0.12)\end{array}$ & $\begin{array}{l}-0.06 * * \\
(0.15)\end{array}$ & ${ }_{(0.46)}^{0.11}$ ** & $\begin{array}{c}-0.32 \\
(0.31)\end{array}$ & $\begin{array}{l}-0.45^{* *} \\
(0.34)\end{array}$ \\
\hline TIME & $\begin{array}{l}0.19^{* *} \\
(0.13)\end{array}$ & $\begin{array}{c}-0.33^{* *} \\
(0.14)\end{array}$ & $\begin{array}{c}-0.27^{* *} \\
(0.20)\end{array}$ & $\begin{array}{l}0.33^{* *} \\
(0.36)\end{array}$ & $\begin{array}{c}-0.05^{* *} \\
(0.34)\end{array}$ & $\begin{array}{c}-0.19^{* *} \\
(0.42)\end{array}$ \\
\hline $\mathrm{TIME}^{2} / 100$ & $\begin{array}{c}-0.17^{* *} \\
(0.04)\end{array}$ & $\underbrace{1.06}_{(0.04)}$ & ${ }_{(0.04)}^{0.99}$ ** & $\begin{array}{c}-0.44^{* *} \\
(0.06)\end{array}$ & $\begin{array}{l}0.27^{* *} \\
(0.05)\end{array}$ & $\begin{array}{l}0.57^{* *} \\
(0.05)\end{array}$ \\
\hline ENTRY $\times$ NO QUALIFICATIONS & $\begin{array}{l}1.09 \\
(0.10)\end{array}$ & $\begin{array}{l}1.622^{* *} \\
(0.11)\end{array}$ & $\begin{array}{l}1.74^{* *} \\
(0.15)\end{array}$ & ${ }_{(0.15)}^{0.84}{ }^{* *}$ & $\begin{array}{l}1.29^{* *} \\
(0.16)\end{array}$ & $\begin{array}{l}0.25 \text { ** } \\
(0.15)\end{array}$ \\
\hline ENTRY $\times$ O LEVELS & $\begin{array}{l}0.68^{* *} \\
(0.04)\end{array}$ & $\begin{array}{l}1.222^{* *} \\
(0.04)\end{array}$ & $\begin{array}{l}0.41 \\
(0.04)\end{array}$ & $\begin{array}{l}0.54 \\
(0.06)\end{array}$ & $\begin{array}{l}0.61 \\
(0.06)\end{array}$ & $\begin{array}{c}-0.599^{* *} \\
(0.05)\end{array}$ \\
\hline ENTRY $\times$ DEGREE OR A LEVELS & $\begin{array}{c}-0.18^{* *} \\
(0.12)\end{array}$ & $\begin{array}{c}-0.26^{* *} \\
(0.13)\end{array}$ & $\begin{array}{c}-0.38^{* *} \\
(0.16)\end{array}$ & $\begin{array}{c}-0.17^{* *} \\
(0.18)\end{array}$ & $\begin{array}{c}-0.04{ }^{* *} \\
(0.18)\end{array}$ & $\begin{array}{c}-0.48^{* *} \\
(0.16)\end{array}$ \\
\hline
\end{tabular}

Table 3: Additions controls included in dynamic mixed multinomial logit model of labor market outcomes model with persistent unobserved heterogeneity represented by three mass points. Standard errors in parenthesis. * indicates significance at the $5 \%$ level and ${ }^{* *}$ indicates significance at the $1 \%$ level.

that in several years around the middle of the sample the simulated proportion of women in nonemployment exceeds the observed proportion. However the discrepancy is never more than three percentage points and is distributed essentially equally between the six employment states. Hence inferences conditional on employment remain accurate. The second method used to assess the fit of the model involves focusing on the dynamic structure of women's labor market outcomes reported in Table 1. The predicted pattern of women's transitions between labor market states is summarized in Table 4 in Appendix II. A comparison of Tables 1 and 4 reveals that the model accurately predicts the high levels of persistence in women's labor market outcomes, and also generates variation in the levels of persistence over time which matches that observed in the sample.

\subsection{Persistent Unobserved Heterogeneity}

The three values of persistent unobserved heterogeneity, $\alpha^{r}$ for $r=1,2,3$, are almost equally spaced, taking values of $0,2.08$ and 4.39. $13 \%$ of the women are found to have the lowest value of unobserved heterogeneity, $25 \%$ have the highest value and the remaining $62 \%$ have the intermediate value of unobserved heterogeneity.

The effect of the persistent unobserved heterogeneity on women's payoffs is consistent with the interpretation of unobserved heterogeneity as unobserved productivity. In particular, the estimated $\theta$ parameters satisfy the ordering $\theta_{\text {HNM-FT }}=1>\widehat{\theta}_{\text {LNM-FT }}>\widehat{\theta}_{\text {M-FT }}$ and $\widehat{\theta}_{\text {HNM-PT }}>\widehat{\theta}_{\text {LNM-PT }}>\widehat{\theta}_{\text {M-PT }}$, which is consistent with high productivity women facing relatively low costs of obtaining jobs in high occupations or finding it less onerous to hold jobs in high occupations than women of low productivity. This ordering of the $\theta$ parameters thus implies that high productivity women are, ceteris paribus, more likely to be employed in high occupations than low productivity women. Finally, given that all of the $\theta$ parameters are positive, the higher a woman's unobserved productivity the lower the probability that she is non-employed.

Simulation methods are employed in order to determine the effects of various individual char- 
acteristics and unobserved heterogeneity on the occupational attainment of women in full-time and part-time employment. The design of this simulation is outlined here and is described in more detail in Appendix I. Attention is focused on a baseline case: a woman with no qualifications, no children or partner and whose father was from a lower social class at the time of the woman's birth. The value of the woman's persistent unobserved heterogeneity is fixed at the estimated value of $\alpha^{2}$, the medium value of persistent unobservables. Starting with the woman's first year in the labor market, the woman's probabilities of being employed in each occupational category if she works full-time and if she works part-time are computed. A comparison of the probability of the woman being employed in a particular occupational category is she works full-time with her probability of being employed in the same occupational category if she works part-time reveals the effect of part-time employment on the woman's potential occupational attainment. Importantly, this comparison is net of any composition effects. Based on the stochastic specification of the model, the woman's actual labor market choice in this year is also determined. This process is repeated sequentially for each year up to the time when the woman is age forty years. Throughout this simulation the woman's previous labor market outcomes are updated in accordance with her previous labor market choices. This procedure is repeated a large number of times so as to minimize the impact of simulation noise. The effect of a change in a particular characteristic on the woman's occupational attainment is obtained by repeating this simulation but changing the value of the characteristic of interest. For example, the effect of an increase in the value of persistent unobservables from $\alpha^{2}$ to $\alpha^{3}$ is determined by comparing a woman's probabilities of working in each occupational category if she works full-time and if she works part-time when she has baseline characteristics with the corresponding probabilities if the value of her unobserved heterogeneity is $\alpha^{3}$ but all other characteristics are as in the baseline case. The effects of changes in other explanatory variables are obtained in a similar fashion.

It should be noted that, given the dynamic structure of the model, any change in individual characteristics, such as in increase in persistent unobserved heterogeneity or an increase in qualifications, affects a woman's occupational attainment in two ways. Firstly, there is a static effect: a change in an individual characteristic affects a woman's net payoff from each labor market state and thus affects her likelihood, conditional on her employment state, of being in a particular occupational category. Secondly, there is a dynamic effect: a change in an individual characteristic affects a woman's actual labor market choice and via the effect of pervious labor market outcomes on the woman's current net payoffs the woman's future probabilities of working in particular occupations are altered.

Figure 3 shows the effect of persistent unobservables on a woman's occupational attainment. As expected, conditional on either full-time or part-time employment, higher values of persistent unobservables are associated with higher occupational attainment. The part-time occupations gap 


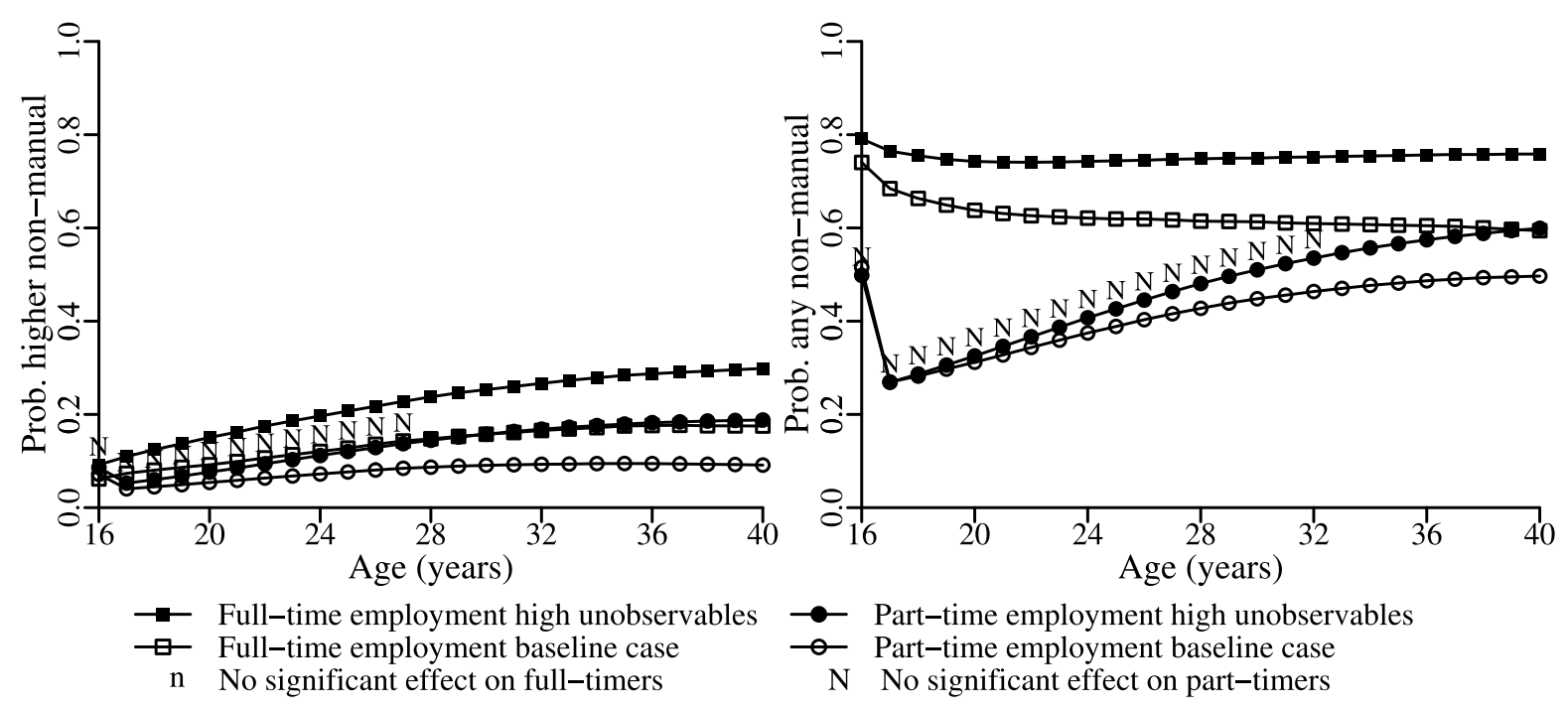

Figure 3: Effect of increasing the value of a woman's persistent unobserved heterogeneity from $\alpha^{2}$ to $\alpha^{3}$. See text for a description of the baseline case. Unless otherwise indicated all effects are significant at the $5 \%$ level.

is increasing in the value of the woman's persistent unobserved heterogeneity and thus higher values of persistent unobservables benefit a woman more if she is working full-time than if she is working part-time. This is true at both levels of occupational attainment, however the effect of unobservables on the part-time occupations gap is largest when measured at the divide between manual and nonmanual occupations.

If unobserved heterogeneity is taken to represent unobserved productivity then this results suggests that higher productivity is rewarded by jobs in higher occupations. However, the occupational rewards to higher productivity are lower for woman working part-time than for women in full-time employment. Furthermore, high productivity women working part-time are particularly disadvantaged, relative to full-timers, in terms of there likelihood of obtaining employment in non-manual occupations; the occupational disadvantage suffered by high productivity women working part-time is less when measured in terms of their probability of obtaining a job in a higher non-manual occupation.

As discussed above, without placing further structure on the problem, it is impossible to determine if the large part-time occupations gap amongst women with high values of persistent unobserved heterogeneity is due to superior occupational opportunities available to women with high values of persistent unobservables in full-time employment or to preference variation. However, if it is assumed that women do not have preferences which vary with their unobserved productivity then the large part-time occupations gap observed amongst high productivity women represents better occupational opportunities for high productivity women in full-time employment than for similarly productive women working part-time.

Before proceeding to discuss the effects of individuals characteristics, the implications of ignoring 
the presence of persistent unobserved heterogeneity are explored. Tables 6 and 7 in Appendix III detail the parameter estimates for a dynamic multinomial logit model of women's labor market outcomes without persistent unobserved heterogeneity. The Bayesian Information Criterion (Schwartz, 1978) for the model without unobserved heterogeneity exceeds that for the model with unobserved heterogeneity. Thus, after imposing a penalty for the additional complexity introduced by including persistent unobserved heterogeneity, the model with persistent unobserved heterogeneity dominates the model without unobserved heterogeneity. Furthermore, there are substantial differences between the two sets of parameter estimates. In particular, the model with persistent unobserved heterogeneity suggests lower coefficients on the lagged dependent variables and experience terms than the model without persistent unobservables. Thus when persistent unobservables are omitted the model over estimates effects of a woman's past labor market outcomes on her current labor market outcomes. This finding is consistent with results of Heckman (1981). Also, there are biases in the estimates of the coefficients on individual and household level variables when persistent unobservables are omitted including a downwards bias in the effects of qualifications and an upwards bias in the effects of children. This discussion suggests that persistent unobserved heterogeneity plays an important role in correctly modelling women's occupational outcomes and omitting persistent unobservables is likely to result in misleading conclusions regarding the determinants of women's labor market outcomes. Hence in the remaining discussion attention is restricted to the model which includes persistent unobserved heterogeneity.

\subsection{Qualifications}

The parameter estimates in Table 2 show that qualifications have large and significant effects on women's payoffs from the various labor market states. Specifically, all three levels of qualifications significantly increase a woman's payoff from holding a job in a higher non-manual occupation, either full-time or part-time, relative to having no qualifications. Similarly, relative to having no qualifications, all three levels of qualifications significantly increase a woman's payoff from holding a full-time job in a lower non-manual occupation, and A levels and degree level qualifications significantly increase a woman's payoff from holding a part-time job in a lower non-manual occupation.

The results of simulations, illustrated in Figure 4, show how qualifications affect a woman's occupational attainment over time. Increases in qualifications are associated with higher occupational attainment measured in terms of both a woman's likelihood of holding a job in a non-manual occupation and her likelihood of holding a job in a higher non-manual occupation. Measured in terms of the effect on the probability of a woman holding a job in a higher non-manual occupation the largest marginal effect of qualifications occurs when the level of the woman's highest qualifications increases from A levels to a degree level qualification. In contrast, an increase in qualifications from 

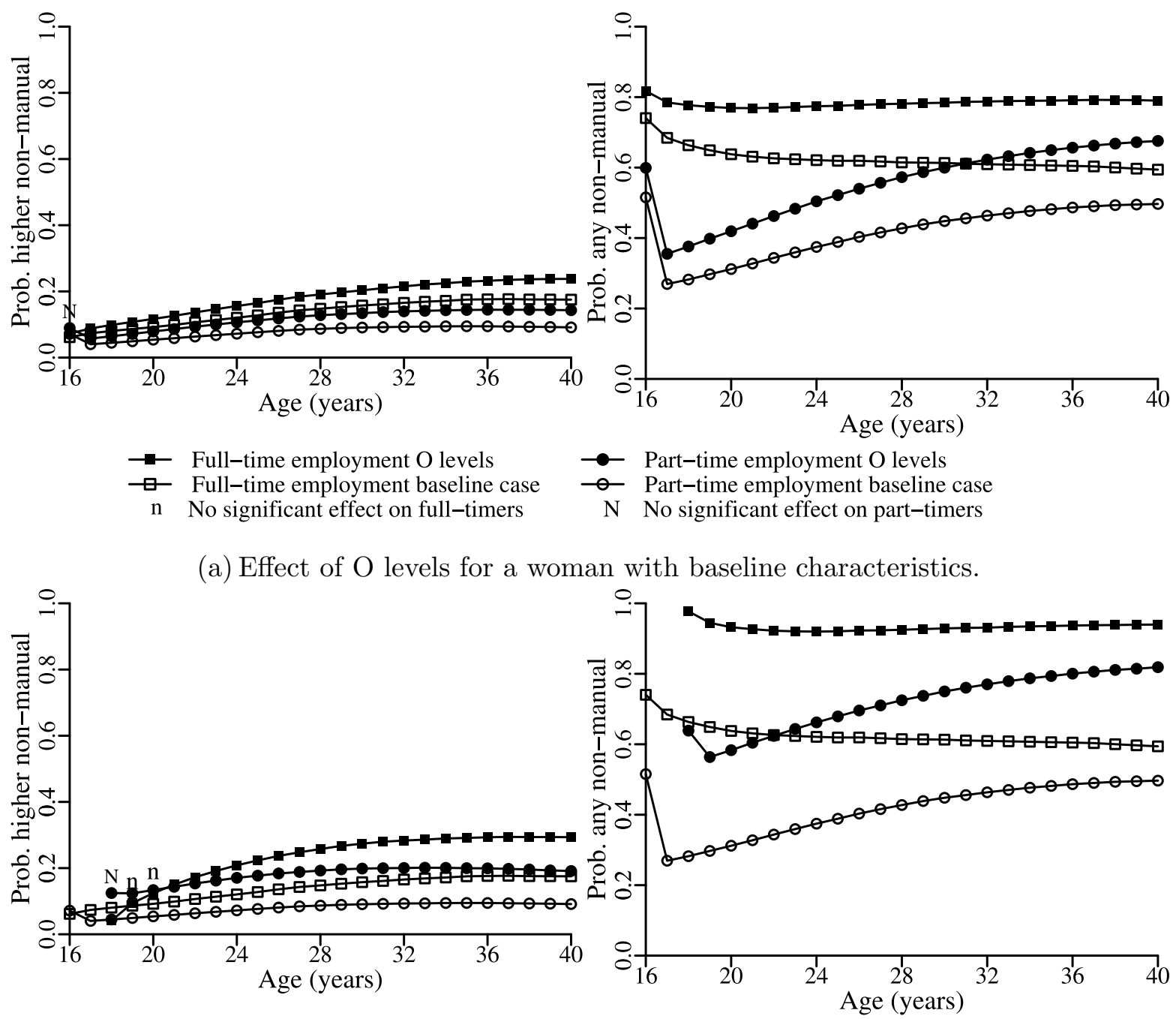

$\rightarrow$ Full-time employment A levels
$\square-$ Full-time employment baseline case

$\rightarrow-$ Part-time employment A levels
N Part-time employment baseline case
N No significant effect on part-timers

$n$ No significant effect on full-timers N No significant effect on part-timers

(b) Effect of A levels for a woman with baseline characteristics.
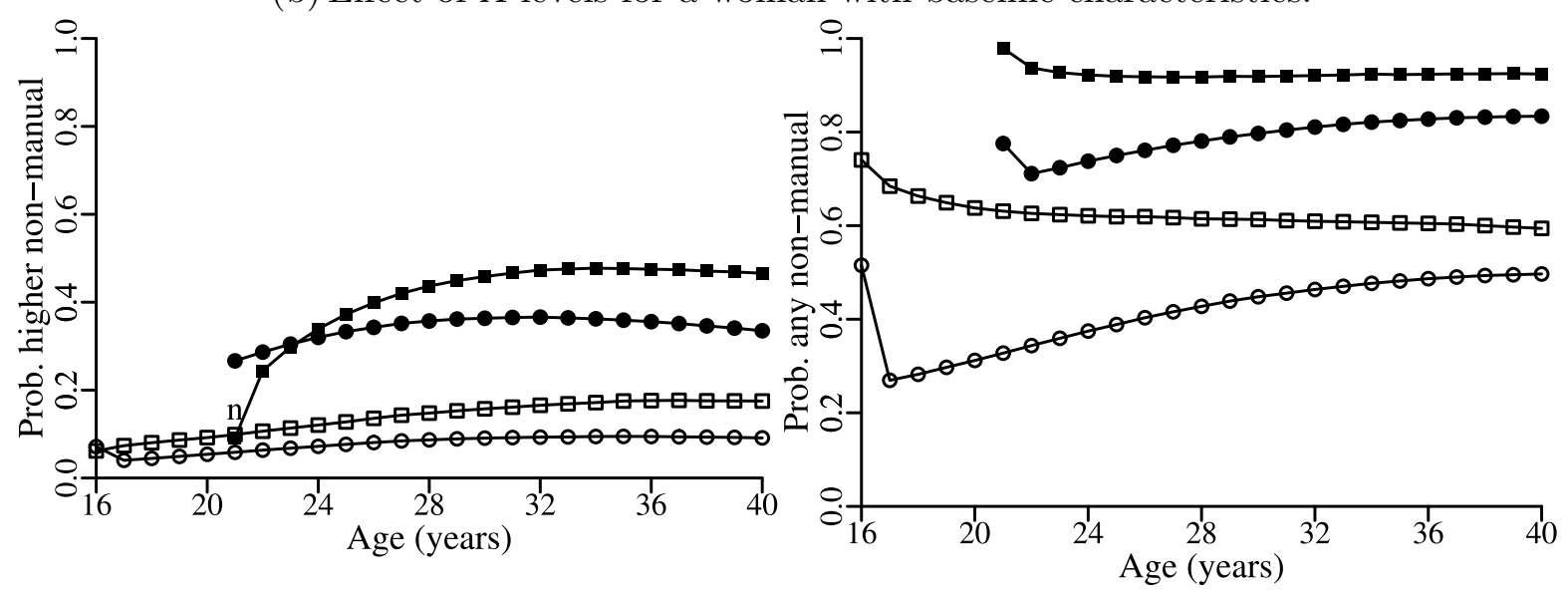

Full-time employment degree
n No significant effect on full-timers

$\multimap \quad$ Part-time employment degree

- Part-time employment baseline case

$\mathrm{N}$ No significant effect on part-timers

(c) Effect of a degree for a woman with baseline characteristics.

Figure 4: Effect of changes in qualifications for a woman with baseline characteristics. See text for a description of the baseline case. Unless indicated all effects are significant at the $5 \%$ level. 
no qualifications to $\mathrm{O}$ levels has the largest effect on a woman's probability of holding a job in any non-manual occupation.

The effect of qualifications on the part-time occupations gap depends on the level of the qualification, the woman's age and the level at which occupational attainment is measured. Measured at the divide between higher non-manual and lower non-manual occupations there is very little variation according to qualifications in the part-time occupations gap at age twenty-five years. Specifically, at age twenty-five years, amongst women with no qualifications or O Levels the proportion of women in full-time employment holding jobs in higher non-manual occupations was approximately 5 percentage points higher than corresponding proportion for women working part-time. For women whose highest qualifications were A levels and degree level qualifications the corresponding part-time occupations gaps were 4.6 percentage points and 3.9 percentage points respectively. However, by age forty years, the part-time occupations gap had increased for all women, irrespective of the level of their qualifications. Furthermore, the part-time occupations gap measured at age forty years was noticeably large for women with degree level qualifications than for women with qualifications below degree level.

The part-time occupations gap measured at the divide between manual and non-manual occupations displays a different pattern of variation. At age twenty-five years the part-time occupations gap was high, around 25 percentage points, for women with qualifications below degree level and smallest, approximately 17 percentage points, for women with degree level qualifications. Thus, for young women, degree level qualifications benefited women in part-time employment relative to women working full-time. As the women become older the benefit of degree level qualifications diminished. Indeed, by age forty years, the part-time occupations gap was essentially equal across women with different levels of qualifications.

\subsection{Household Structure}

A woman's cohabitation status is a significant determinant of her payoffs from the different labor market states. Specifically, the results in Table 2 show that women who are cohabiting have significantly lower payoffs from all employment states than single women, and the effect of cohabiting is much larger in magnitude for full-time employment than for part-time employment.

Figure 5(a) compares the probability of a woman with baseline characteristics obtaining a job in a higher non-manual occupation and in any non-manual occupation if she works full-time and if she works part-time with the corresponding probabilities for a woman who is cohabiting throughout the sample period and whose partner who has an income equal to the sample average of the women's partners' incomes but all other characteristics are in the baseline case. This comparison reveals that women who are cohabiting are slightly more likely than single women to be employed in higher 
non-manual occupations if they work full-time, and are essentially equally likely to be employed in higher non-manual occupations if they work part-time. However, the effect of cohabiting on a woman's probability of working in a higher non-manual occupation if she works full-time or part-time is insignificant. In contrast, at some ages, a woman's cohabitation status does significantly affect her probability of working in any non-manual occupation if she works full-time. Specifically, between the ages of sixteen and thirty-four years cohabiting women are significantly more likely, at the $5 \%$ level, to be employed in non-manual occupations if they work part-time than single women. Therefore, during the first half of the sample period, the part-time occupations gap, measured in terms of the probability of a woman obtaining employment in any non-manual occupation, was smaller for cohabiting women than for single women.

A woman's partner's pay only significantly affects the woman's payoffs from full-time and parttime employment in manual occupations. The direction of this effect is negative implying that a woman's payoff from working either full-time or part-time in a manual occupation is decreasing in her partner's pay. This finding is consistent with women whose partners who have high incomes being relatively unlikely to accept employment in low quality jobs. The magnitudes of the effects of a woman's partner's pay on her payoffs are small and thus these effects not explored in any further detail.

Within the labor supply literature it is well established that child-bearing and the associated caring responsibilities cause a substantial reduction in women's labor supply at both the extensive and intensive margins (Blau and Robins, 1988; Miller, 1993; Mroz, 1987; Ribar, 1995). The results presented in Table 2 confirm a strong negative effect of young children on women's labor force participation and, amongst women in employment, a switch from full-time employment into parttime employment.

Figure 5(b) illustrates the probability of a woman who has a one child at age twenty-four years and all other characteristics as in the baseline case working in a higher non-manual occupation and in any non-manual occupation if she works full-time and if she works part-time. Also shown are the corresponding probabilities for a woman with baseline characteristics. Figure 5(b) shows that women who have children have higher occupational outcomes than childless women. ${ }^{13}$ Specifically, having a child increases a woman's probability of obtaining a job in a higher non-manual occupation by an average of around 2 percentage points, irrespective of her hours of work; the part-time occupations gap measured at the divide between higher non-manual and lower non-manual occupations

\footnotetext{
${ }^{13}$ Prior to the time of the child's birth the effect of a child on a woman's occupations attainment occurs entirely though the effect of fertility expectations. The age at which a woman plans to have her first child significantly affects her choice of occupation: the older a woman when she has her first child the higher her payoff from working in a higher or lower non-manual occupation. This is true for women in both full-time and part-time employment. Thus women who plan to have children tend to have higher occupational outcomes when they are young than women who never have children. The number of children that woman plans to have partially offsets this effect. However, for the example shown in Figure 5(b), the former effect dominates.
} 

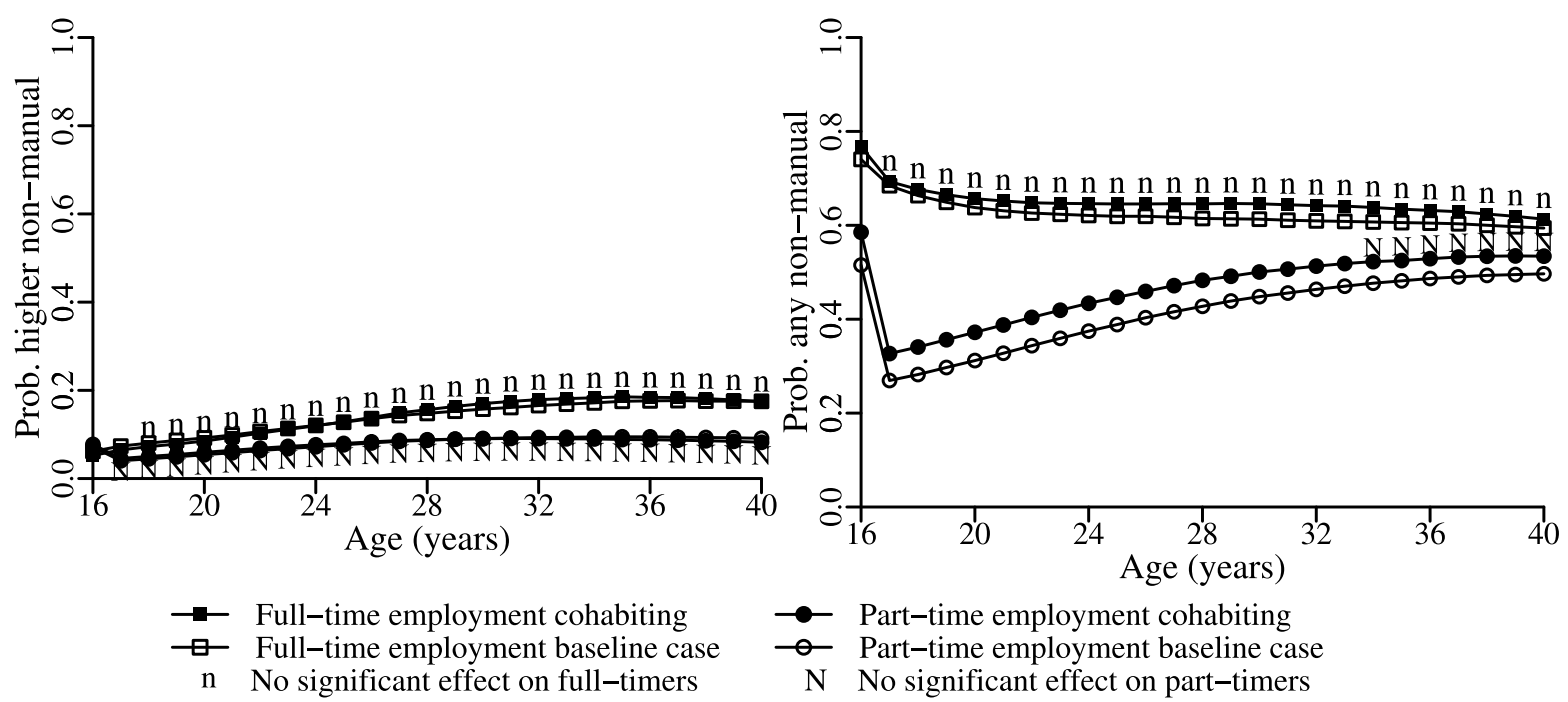

(a) Effect of cohabiting for a woman with baseline characteristics.
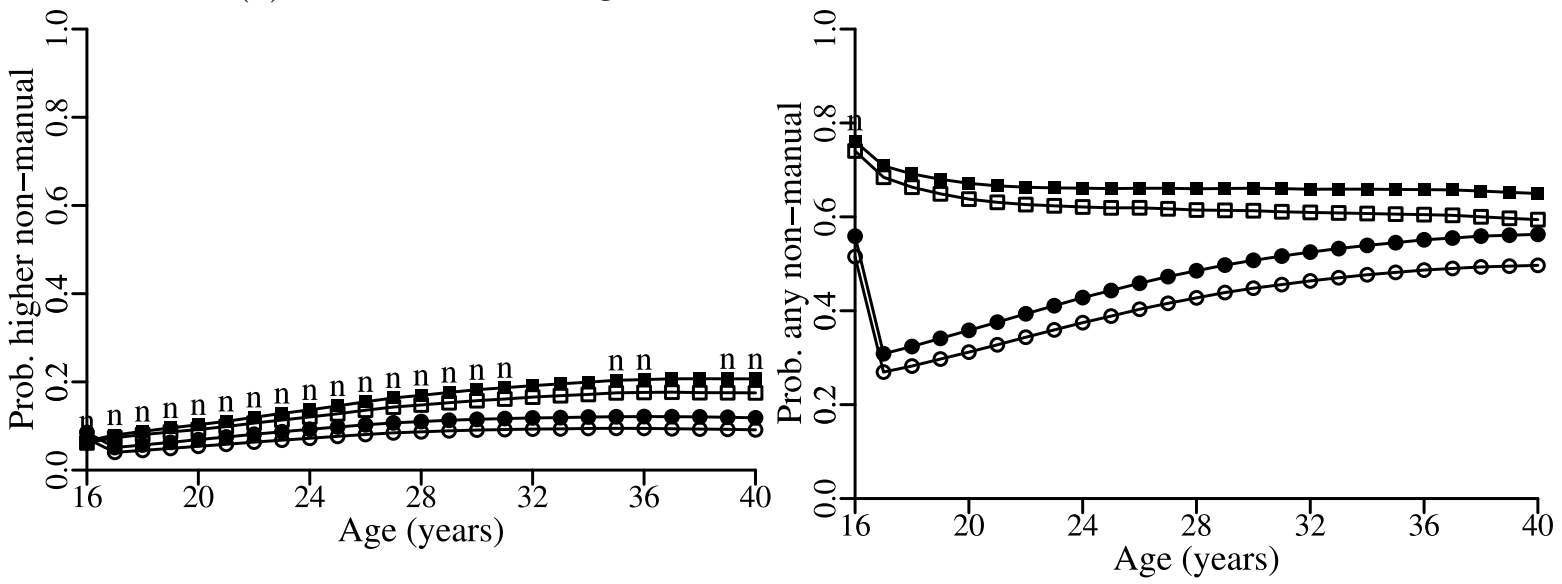

- Full-time employment child
$\square-$ Full-time employment baseline case

$\rightarrow-$ Part-time employment child
$\rightarrow-$ Part-time employment baseline case
N No significant effect on part-timers

$\mathrm{n}$ No significant effect on full-timers $\quad \mathrm{N}$ No significant effect on part-timers

(b) Effect of having one child at age 26 years for a woman with baseline characteristics.
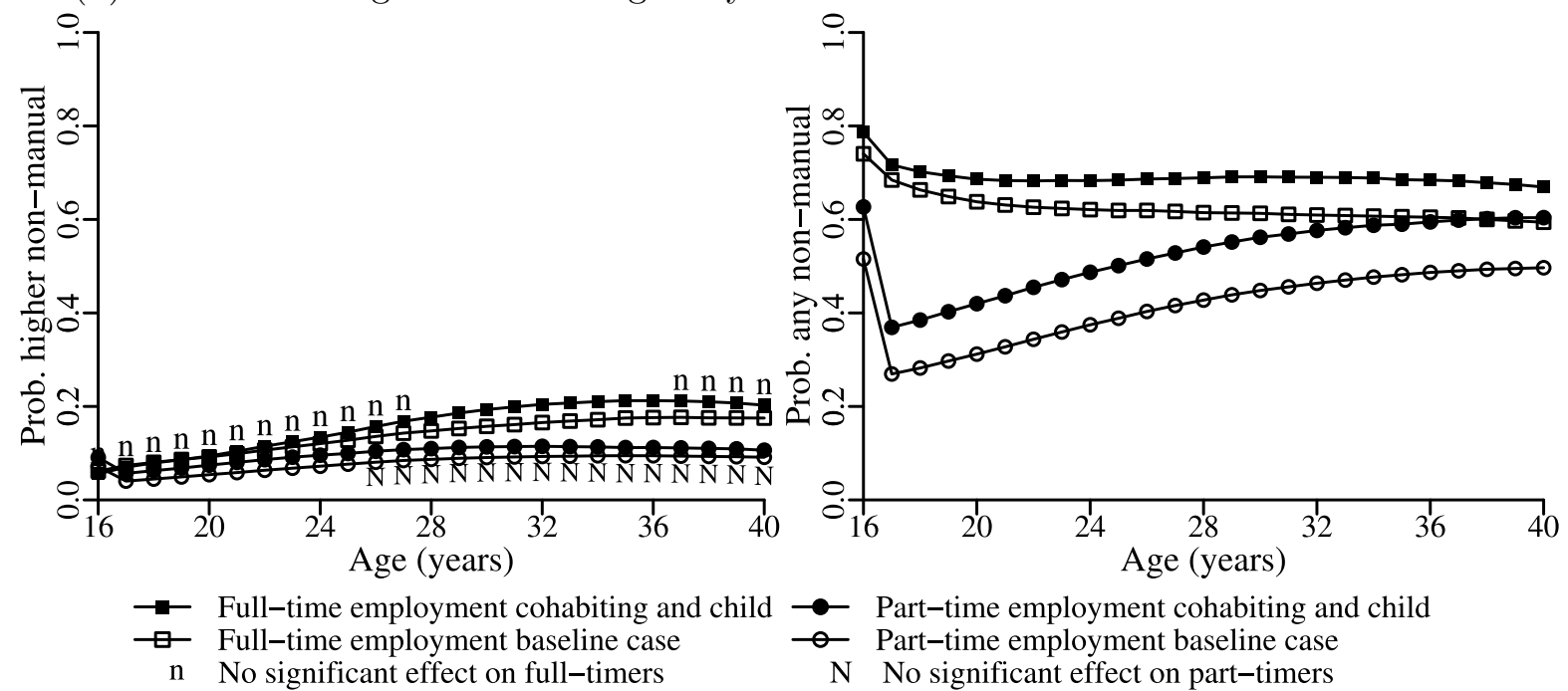

(c) Effect of cohabiting and having one child at age 26 years for a woman with baseline characteristics.

Figure 5: Effects of household structure variables a woman with baseline characteristics. See text for a description of the baseline case. Unless indicated all effects are significant at the $5 \%$ level. 
is essentially invariant with respect to whether or not a woman has a child. The effect of having a child on a woman's probability of holding a job in a non-manual occupation is larger: having a child increases a woman's probability of holding a job in a non-manual occupation is she works full-time by an average of 4.3 percentage points, and having a child increases a probability of holding a job in a non-manual occupation is she works part-time by an average of 5.6 percentage points. Thus women with children experience a smaller part-time occupational penalty, measured at the divide between manual and non-manual occupations, than childless women.

Figure 5(c) compares the probability of a woman with baseline characteristics obtaining a job in a higher non-manual occupation and in any non-manual occupation if she works full-time and if she works part-time with the corresponding probabilities for a woman who has one child at age twentyfour years and is cohabiting throughout the sample period. The combined effects of cohabiting and having a child are in the same direction as the effect of having a child; women who are cohabiting and have a child have higher occupation attainment, irrespective of their employment status than single childless women. The combined effects of cohabiting and having a child on a woman's probability of obtaining a job in any non-manual occupation are much larger in magnitude than the effect of a child for a single woman.

At this point it is appropriate to consider the reason for the relatively low occupational attainment of women in part-time employment. One potential explanation for the low occupational attainment of women in part-time employment is that women who have children have low attachment to the labor market: they place a high value on spending time with their children and thus have a strong preference for part-time employment over full-time employment, and also prefer low status jobs to high status jobs as they are less stressful or demanding (see Bonney, 2005; Hakim, 2000; Harris, 1993; Rubery et al., 1994). If this explanation is valid then women with children in part-time employment should have lower occupational attainment than women without children who are working part-time. However, Figures 5(b) and 5(c) reveal the opposite: women in part-time employment with children actually have a higher probability of being employed in a higher non-manual occupation and in any non-manual occupation than women without children. Thus, although women with children are both more likely to be non-employed and less likely to be working full-time than women without children, there is no evidence that women with children who choose to work part-time are less committed to their careers than childless women who choose to work part-time. It appears instead that women with children are more selective in terms of the quality of jobs that they are willing to accept than childless women. Women with children who are cohabiting appear to be particularly selective in terms of whether or not they are willing to accept jobs in manual occupations. 


\subsection{Family Background}

The only significant effects of family background, as measured by a woman's father's social class at the time of the woman's birth, are to decrease a woman's payoff from working full-time in a manual occupation and to increase her payoff from working part-time in a higher non-manual occupation. Figure 6 shows how family background impacts on the occupational attainment of women in fulltime and part-time employment. As expected having a father from a higher social class increases women's occupational attainment in both full-time and part-time employment, thus confirming the findings of Erikson and Goldthorpe (1992), Heath and Payne (1999) and Peters (1992). However family background effects are small in magnitude.

In terms of the effect of family background on the part-time occupations gap, an increase a woman's father's social class from lower to higher increases the probability of the woman working in a higher non-manual occupation if she works full-time by essentially the same amount as it increases her probability of working in a higher non-manual occupation if she works part-time. The same increase in the woman's father's social class increases the probability of the woman working in any non-manual occupation if she works full-time by slightly more than it increases her probability of working in any non-manual occupation if she works part-time. This is tentative evidence of a larger part-time occupations gap amongst women from more privileged social backgrounds.

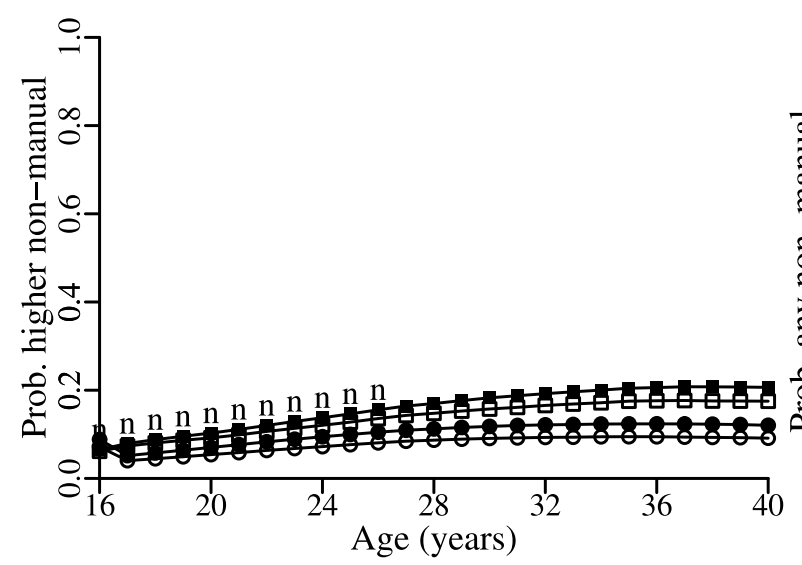

$\rightarrow$ Full-time employment privileged background

$\square$ Full-time employment baseline case

$\mathrm{n}$ No significant effect on full-timers

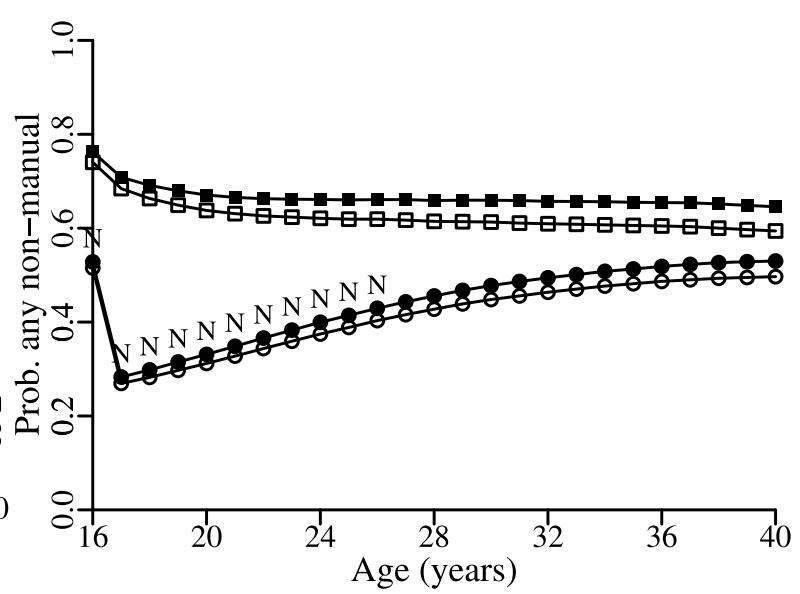

$\rightarrow$ Part-time employment privileged background

- Part-time employment baseline case

N No significant effect on part-timers

Figure 6: Effect of increasing a woman's father's social class from lower to higher for a woman with baseline characteristics. See text for a description of the baseline case.

\section{Conclusion}

Focusing on a cohort of women who were born in 1958, this study has analyzed the determinants of the part-time occupations gap. Instead of focusing on composition effects, this study has looked at the effects of qualifications, household structure and family background on the occupational attainment 
of women in full-time and part-time employment.

The part-time occupations gap has been found to vary across women according to their observed and unobserved individual characteristics. However, for all combinations of individual characteristics considered above there are a substantial differences between a woman's occupational attainment in full-time employment and her occupational attainment in part-time employment. This observation suggests that there exist differences in women's occupational prospects in full-time and part-time employment which affect all women irrespective of their individual characteristics. This finding is consistent with the presence of a constraint on the supply of high quality part-time jobs or with women in part-time employment having a strong preference for jobs in low occupations. To the extent that there is a constraint on the supply of high quality part-time jobs to suitably qualified women there are grounds for policy interventions aiming to equalize the occupational opportunities of women in full-time and part-time employment.

\section{References}

Akerlof, G. A. And Yellen, J. L. (1990), The Fair Wage-effort Hypothesis and Unemployment, The Quarterly Journal of Economics, vol. 105(2): pp. 255-283.

Atrostic, B. K. (1982), The Demand for Leisure and Nonpecuniary Job Characteristics, American Economic Review, vol. 72(3): pp. 428-440.

Blackwell, L. (2001), Occupational Sex Segregation and Part-time Work in Modern Britain, Gender, Work and Organisation, vol. 8(2): pp. 146-163.

Blau, D. M. and Robins, P. K. (1988), Child-care Costs and Family Labor Supply, The Review of Economics and Statistics, vol. 70(3): pp. 374-381.

Bonney, N. (2005), Overworked Britons? Part-time Work and Work-life Balance, Work, Employment 85 Society, vol. 19(2): pp. 391-401.

Boskin, M. J. (1974), A Conditional Logit Model of Occupational Choice, Journal of Political Economy, vol. 82(2): pp. 389-398.

Bover, O. (1991), Relaxing Intertemporal Separability: A Rational Habits Model of Labor Supply Estimated from Panel Data, Journal of Labor Economics, vol. 9(1): pp. 85-100.

Brown, C. (1980), Equalizing Differences in the Labor Market, The Quarterly Journal of Economics, vol. 94(1): pp. 113-134.

Cain, G. G. and Dooley, M. D. (1976), Estimation of a Model of Labor Supply, Fertility, and Wages of Married Women, Journal of Political Economy, vol. 84(4): pp. 179-199.

CARD, D. (1996), The Effect of Unions on the Structure of Wages: A Longitudinal Analysis, Econometrica, vol. 64(4): pp. 957-979.

Card, D. and DiNardo, J. E. (2002), Skill-biased Technological Change and Rising Wage In- 
equality: Some Problems and Puzzles, Journal of Labor Economics, vol. 20(4): pp. 733-783.

Collins, D., Deepchand, K., Fitzgerald, R., Perry, J., Bynner, J., Butler, N., Ferri, E., Shepherd, P. And Smith, K. (2001), NCDS6 - Survey Technical Report: Stability, Change and Development In The British Population, Joint Center for Longitudinal Research.

Connolly, S., Micklewright, J. And Nickell, S. (1992), The Occupational Success of Young Men Who Left School at Sixteen, Oxford Economic Papers, vol. 44(3): pp. 460-479.

Dolton, P. J. and Makepeace, G. H. (1990), The Earnings of Economics Graduates, Economic Journal, vol. 100(399): pp. 237-250.

Dynan, K. E. (2000), Habit Formation in Consumer Preferences: Evidence from Panel Data, American Economic Review, vol. 90(3): pp. 391-406.

Elliott, J., Dale, A. And Egerton, M. (2001), The Influence of Qualifications on Women's Work Histories, Employment Status and Earnings at Age 33, European Sociological Review, vol. 17(2): pp. $145-168$.

Erikson, R. And Goldthorpe, J. (1992), The Constant Flux: A Study of Class Mobility in Industrial Societies, Oxford: Clarendon Press.

Francesconi, M. (2002), A Joint Dynamic Model of Fertility and Work of Married Women, Journal of Labor Economics, vol. 20(2): pp. 336-380.

Glaeser, D. L., Edward L. And Sacerdote, B. (2002), An Economic Approach to Social Capital, Economic Journal, vol. 112(483): pp. 437-458.

Greenhalgh, C. and Stewart, M. (1985), The Occupational Status and Mobility of British Men and Women, Oxford Economic Papers, vol. 37(1): pp. 40-71.

Grimshaw, D. And Rubery, J. (2001), The Gender Pay Gap: A Research Review, Equal Opportunities Commission: Research Discussion Series.

Gritz, R. M. (1993), The Impact of Training on the Frequency and Duration of Employment, Journal of Econometrics, vol. 57(1-3): pp. 21-51.

Hakim, C. (2000), Work-Lifestyle Choices in the 21st Century: Preference Theory, Oxford: Oxford University Press.

Harper, B. And Mohammad, H. (1997), Occupational Attainment of Men in Britain, Oxford Economic Papers, vol. 49(4): pp. 638-650.

HARris, R. I. D. (1993), Part-time Female Earnings: An Analysis Using Northern Ireland NES Data, Applied Economics, vol. 25(1): pp. 1-12.

Heath, A. And Payne, C. (1999), Twentieth Century Trend in Social Mobility in Britain, University of Oxford Centre for Research into Elections and Social Trends Working Paper 70.

Heckman, J. J. (1978), A Partial Survey of Recent Research on the Labor Supply of Women, American Economic Review, vol. 68(2): pp. 200-207.

Heckman, J. J. (1981), The Incidental Parameters Problem and the Problem of Initial Condition in Estimating a Discrete Time-Discrete Data Stochastic Process, in C. Manski and D. McFadden 
(Editors), Structural Analysis of Discrete Data and Econometric Applications, chap. 4, pp. 179197, Cambridge: The MIT Press.

Heckman, J. J. And Singer, B. (1984), A Method for Minimizing the Impact of Distributional Assumptions in Econometric Models for Duration Data, Econometrica, vol. 52(2): pp. 271-320.

Hyslop, D. (1999), State Dependence, Serial Correlation and Heterogeneity in Intertemporal Labor Force Participation of Married Women, Econometrica, vol. 67(6): pp. 1255-1294.

Jacobs, S. (1999), Trends in Women's Career Patterns and in Gender Occupational Mobility in Britain, Gender, Work and Organization, vol. 6(1): pp. 32-46.

Keane, M. P. And Wolpin, K. I. (1997), The Career Decisions of Young Men, Journal of Political Economy, vol. 105(3): pp. 473-522.

Krueger, A. And Rouse, C. (1998), The Effect of Workplace Education on Earnings, Turnover, and Job Performance, Journal of Labor Economics, vol. 16(1): pp. 61-94.

Krueger, A. B. And Summers, L. H. (1988), Efficiency Wages and the Inter-industry Wage Structure, Econometrica, vol. 56(2): pp. 259-293.

Kubin, I. AND Prinz, A. (2002), Labour Supply with Habit Formation, Economics Letters, vol. 75(1): pp. 75-79.

Lemaître, G., Marianna, P. And van Bastelaer, A. (1997), International Comparisons of Part-time Work, OECD Economic Studies, vol. 29(II): pp. 139-152.

Machin, S. (1997), The Decline of Labour Market Institutions and the Rise in Wage Inequality in Britain, European Economic Review, vol. 41(3-5): pp. 647-657.

Manning, A. And Petrongolo, B. (2005), The Part-time Pay Penalty, CEP discussion paper.

Martin, J. And Roberts, C. (1984), Women and Employment: A Lifetime Perspective, London: HMSO.

McRAe, S. (1993), Returning to Work After Childbirth: Opportunities and Inequalities, European Sociological Review, vol. 9(2): pp. 125-137.

Miller, C. F. (1993), Part-time Participation over the Life Cycle among Married Women Who Work in the Market, Applied Economics, vol. 25(1): pp. 91-99.

Moore, M. P. And Ranjan, P. (2005), Globalisation vs Skill-Biased Technological Change: Implications for Unemployment and Wage Inequality, Economic Journal, vol. 115(503): pp. 391-422.

Mroz, T. (1987), The Sensitivity of an Empirical Model of Married Women's Hours of Work to Economic and Statistical Assumptions, Econometrica, vol. 55(1): pp. 765-799.

Nerlove, M. And Press, S. J. (1973), Univariate and Multivariate Log-linear and Logistic Models, RAND-R1306-EDA/NHI, Santa Monica.

Nickell, S. (1982), The Determinants of Occupational Success in Britain, Review of Economic Studies, vol. 49(1): pp. 43-53.

O'Brien, J. and Prescott-Clarke, P. (1987), NCDS4 - Survey Technical Report, NOP Market Reseach Ltd. 
Olson, C. A. (2002), Do Workers Accept Lower Wages in Exchange for Health Benefits?, Journal of Labor Economics, vol. 20(2): pp. 91-114.

Perry, S. (1988), The Supply of Female Part-time Labour over the Life Cycle, Applied Economics, vol. 20(12): pp. 1579-1587.

Peters, H. E. (1992), Patterns of Intergenerational Mobility in Income and Earnings, The Review of Economics and Statistics, vol. 74(3): pp. 456-466.

Prescott-Clarke, P., Moon, N. and Manley, D. (1993), NCDS5 - Survey Technical Report, SCPR, NOP and RSGB.

Ribar, D. C. (1995), A Structural Model of Child Care and the Labor Supply of Married Women, Journal of Labor Economics, vol. 13(3): pp. 558-597.

Rosen, S. (1972), Learning and Experience in the Labor Market, Journal of Human Resources, vol. $7(3)$ : pp. $326-342$.

Rubery, J. (1998), Part-time Work: A Threat to Labour Standards?, in C. Fagan and J. O'Reilly (Editors), Part-time Prospects: An International Comparison of Part-time Work in Europe, North America and the Pacific Rim, pp. 137-155, London, Routledge.

Rubery, J., Horrell, S. And Burchell, B. (1994), Part-time Work and Gender Inequality, in A. MacEwen Scott (Editor), Gender Segregation and Social Change, pp. 204-234, Oxford: Oxford University Press.

Rust, J. (1996), Numerical Dynamic Programming in Economics, in H. M. Amman, D. A. Kendrick and J. Rust (Editors), Handbook of Computational Economics, vol. 1, chap. 14, pp. 619-729, Elsevier.

Schmidt, P. And Strauss, R. P. (1975), The Prediction of Occupation Using Multiple Logit Models, International Economic Review, vol. 16(2): pp. 471-486.

Schwartz, G. (1978), Estimating the Dimension of a Model, Annals of Statistics, vol. 6: pp. 461-464.

Shapiro, C. And Stiglitz, J. E. (1984), Equilibrium Unemployment as a Worker Discipline Device, American Economic Review, vol. 74(3): pp. 433-444.

Stewart, M. B. and Greenhalgh, C. A. (1984), Work History Patterns and the Occupational Attainment of Women, Economic Journal, vol. 94(127): pp. 493-519.

Woittiez, I. And Kapteyn, A. (1998), Social Interactions and Habit Formation in a Model of Female Labour Supply, Journal of Public Economics, vol. 70(2): pp. 185-205. 


\section{Appendix I: Simulation Design}

This appendix describes the two simulations used in this study.

\section{Simulation for Assessing Goodness of Fit}

This simulation, used to assess the goodness of fit of the model, is based on the sample of women described above. For each woman in the sample a sequence of employment and occupational outcomes is generated based on the estimated parameters. The procedure for doing this is described below.

1. Set $i=1$

2. A value of unobserved heterogeneity of $\alpha_{i}$ is obtained by sampling from the estimated distribution of $\alpha_{i}$. Denote the sampled value $\alpha^{s}$.

3. Set $t=\tau_{i}$

4. Given woman $i$ 's observed characteristics in year $t$ represented by $X_{i, t}$, and her past labor market outcomes represented by $Z_{i, j, t}$ for $j \in \mathcal{S}$ define

$$
\pi_{i, j, t}=\gamma_{j} X_{i, t}+\beta_{j} Z_{i, j, t}+\theta_{j} \alpha_{i}, \text { for } j \in \mathcal{S} \text {. }
$$

5. Draw values of $\varepsilon_{i, j, t}$ for $j \in \mathcal{S}$ by making seven independent draws from a Type I Extreme Value distribution. Construct $U_{i, j, t}=\pi_{i, j, t}+\varepsilon_{i, j, t}$. Woman $i$ chooses labor market state $j$ at time $t$ if and only if $U_{i, j, t}>U_{i, k, t}$ for all $k \neq j$.

6. If $t<T$ set $t=t+1$ and update the values of $Z_{i, j, t}$ to reflect the woman's past labor market choices and return to Step 4 . Else if $i<N$ set $i=i+1$ return to Step 2.

Steps 1-6 are repeated several times in order to minimize the impact of simulation noise.

\section{Simulation for Determining the Effects of Individual Characteristics}

This simulation focuses on an woman with baseline characteristics and is used to determine the effects of individual characteristics on the occupational attainment of women in full-time and parttime employment. Let $X_{i, t}^{B}$ represent the observed baseline characteristics. The value of a woman's unobserved heterogeneity in the baseline case is $\alpha^{2}$. The effect of a change in observed individual characteristics from $X_{i, t}^{B}$ to $X_{i, t}^{N}$ is found as follows.

1. Set $t=1$ 
2. The probabilities of woman $i$ working in a higher non-manual occupation and any non-manual occupation if she works full-time at time $t$ are obtained as follows

$$
\begin{aligned}
P\left(i, \mathrm{HNM} \mid \mathrm{FT}, t ; X_{i, t}^{B}\right) & =\frac{\exp \left(\pi_{i, \mathrm{HNM}-\mathrm{FT}, t}\right)}{\exp \left(\pi_{i, \mathrm{HNM}-\mathrm{FT}, t}\right)+\exp \left(\pi_{i, \mathrm{LNM}-\mathrm{FT}, t}\right)+\exp \left(\pi_{i, \mathrm{M}-\mathrm{FT}, t}\right)}, \\
P\left(i, \mathrm{NM} \mid \mathrm{FT}, t ; X_{i, t}^{B}\right) & =\frac{\exp \left(\pi_{i, \mathrm{HNM}-\mathrm{FT}, t}\right)+\exp \left(\pi_{i, \mathrm{LNM}-\mathrm{FT}, t}\right)}{\exp \left(\pi_{i, \mathrm{HNM}-\mathrm{FT}, t}\right)+\exp \left(\pi_{i, \mathrm{LNM}-\mathrm{FT}, t}\right)+\exp \left(\pi_{i, \mathrm{M}-\mathrm{FT}, t}\right)} .
\end{aligned}
$$

The probabilities of the woman working in a higher non-manual occupation and any non-manual occupation if she works part-time have a similar form.

3. The corresponding probabilities for the case where the woman's observed characteristics are $X_{i, t}^{N}$ are found by repeating Step 2 with $X_{i, t}^{B}$ replaced by $X_{i, t}^{N}$.

4. The woman's actual labor market outcome at time $t$ is determined as described is Step 5 of the previous simulation.

5. If $t<T$ set $t=t+1$ and update the values of $Z_{i, j, t}$ to reflect the woman's past labor market choices and return to Step 2.

Steps 1-5 are repeated a large number of times in order to minimize the impact of simulation noise. The effect of a change in observed individual characteristics from $X_{i, t}^{B}$ to $X_{i, t}^{N}$ is found by comparing $P\left(i, \mathrm{HNM} \mid \mathrm{FT}, t ; X_{i, t}^{B}\right)$ and $P\left(i, \mathrm{HNM} \mid \mathrm{FT}, t ; X_{i, t}^{N}\right)$ and $P\left(i, \mathrm{NM} \mid \mathrm{FT}, t ; X_{i, t}^{B}\right)$ and $P\left(i, \mathrm{NM} \mid \mathrm{FT}, t ; X_{i, t}^{N}\right)$. Standard errors on qualities of interest are found by evaluating these quantities at parameter values drawn independently from several points in the distribution of the parameters. The effect of a change in persistent unobserved heterogeneity is found in a similar way. 


\section{Appendix II: Goodness of Fit}

\begin{tabular}{|c|c|c|c|c|c|c|c|c|}
\hline \multicolumn{2}{|l|}{ 1975-1983 } & \multicolumn{7}{|c|}{$\begin{array}{c}\text { STATE IN YEAR } t+1 \\
\text { HNM-FT LNM-FT M-FT HNM-PT HNM-PT M-PT N-EMP }\end{array}$} \\
\hline \multirow{7}{*}{ STATE IN YEAR $t$} & HNM-FT & $\begin{array}{c}\mathbf{8 4 . 3 9} \\
(0.73)\end{array}$ & $\begin{array}{l}4.39 \\
(0.33)\end{array}$ & $\begin{array}{l}2.36 \\
(0.30)\end{array}$ & $\begin{array}{l}0.63 \\
(0.10)\end{array}$ & $\begin{array}{l}0.26 \\
(0.05)\end{array}$ & $\begin{array}{l}0.51 \\
(0.10)\end{array}$ & $\begin{array}{l}7.47 \\
(0.36)\end{array}$ \\
\hline & LNM-FT & $\begin{array}{l}2.68 \\
(0.16)\end{array}$ & $\begin{array}{r}\mathbf{8 5 . 3 7 7} \\
(0.36)\end{array}$ & $\begin{array}{l}2.51 \\
(0.16)\end{array}$ & $\begin{array}{l}0.15 \\
(0.03)\end{array}$ & $\begin{array}{l}0.55 \\
(0.07)\end{array}$ & $\begin{array}{l}0.57 \\
(0.06)\end{array}$ & $\begin{array}{l}8.18 \\
(0.26)\end{array}$ \\
\hline & M-FT & $\begin{array}{l}2.40 \\
(0.20)\end{array}$ & $\begin{array}{l}4.46 \\
(0.25)\end{array}$ & $\begin{array}{c}\mathbf{8 0 . 6 9} \\
(0.54)\end{array}$ & $\begin{array}{l}0.18 \\
(0.04)\end{array}$ & $\begin{array}{l}0.43 \\
(0.07)\end{array}$ & $\begin{array}{l}1.67 \\
(0.15)\end{array}$ & $\begin{array}{l}10.17 \\
(0.39)\end{array}$ \\
\hline & HNM-PT & $\begin{array}{l}5.01 \\
(0.86)\end{array}$ & $\begin{array}{l}1.35 \\
(0.44)\end{array}$ & $\begin{array}{l}1.50 \\
(0.63)\end{array}$ & $\underset{(2.42)}{\mathbf{8 2 . 2 6}}$ & $\begin{array}{l}0.66 \\
(0.16)\end{array}$ & $\begin{array}{l}0.98 \\
(0.23)\end{array}$ & $\begin{array}{l}8.24 \\
(1.25)\end{array}$ \\
\hline & LNM-PT & $\begin{array}{l}2.62 \\
(0.55)\end{array}$ & $\begin{array}{l}6.79 \\
(1.00)\end{array}$ & $\begin{array}{l}2.09 \\
(0.40)\end{array}$ & $\begin{array}{l}0.46 \\
(0.12)\end{array}$ & $\begin{array}{c}\mathbf{7 4 . 7 3} \\
(2.49)\end{array}$ & $\begin{array}{l}1.87 \\
(0.30)\end{array}$ & $\begin{array}{l}11.44 \\
(1.25)\end{array}$ \\
\hline & M-PT & $\begin{array}{l}2.04 \\
(0.30)\end{array}$ & $\begin{array}{l}3.71 \\
(0.37)\end{array}$ & $\begin{array}{l}6.08 \\
(0.65)\end{array}$ & $\begin{array}{l}0.67 \\
(0.12)\end{array}$ & $\begin{array}{l}1.63 \\
(0.20)\end{array}$ & $\begin{array}{c}\mathbf{7 1 . 7 3} \\
(1.30)\end{array}$ & $\begin{array}{l}14.15 \\
(0.75)\end{array}$ \\
\hline & N-EMP & $\begin{array}{l}4.64 \\
(0.25) \\
\end{array}$ & $\begin{array}{l}8.69 \\
(0.35) \\
\end{array}$ & $\begin{array}{r}5.85 \\
(0.40) \\
\end{array}$ & $\begin{array}{l}1.09 \\
(0.11) \\
\end{array}$ & $\begin{array}{r}2.32 \\
(0.23) \\
\end{array}$ & $\begin{array}{l}4.17 \\
(0.25) \\
\end{array}$ & $\begin{array}{l}73.24 \\
(0.66)\end{array}$ \\
\hline \multicolumn{2}{|l|}{ 1984-1992 } & \multicolumn{7}{|c|}{$\begin{array}{l}\text { STATE IN YEAR } t+1 \\
\text { NM-FT M-FT HNM-PT HNM-PT M-PT N-EMP }\end{array}$} \\
\hline \multirow{7}{*}{ STATE IN YEAR $t$} & HNM-FT & $\begin{array}{c}\mathbf{8 6 . 0 9} \\
(0.46)\end{array}$ & $\begin{array}{l}1.65 \\
(0.13)\end{array}$ & $\begin{array}{l}0.97 \\
(0.12)\end{array}$ & $\begin{array}{l}2.31 \\
(0.18)\end{array}$ & $\begin{array}{l}0.55 \\
(0.08)\end{array}$ & $\begin{array}{l}0.69 \\
(0.10)\end{array}$ & $\begin{array}{l}7.75 \\
(0.37)\end{array}$ \\
\hline & LNM-FT & $\begin{array}{l}2.35 \\
(0.13)\end{array}$ & $\begin{array}{c}\mathbf{8 3 . 8 4} \\
(0.43)\end{array}$ & $\begin{array}{l}0.90 \\
(0.07)\end{array}$ & $\begin{array}{l}0.45 \\
(0.08)\end{array}$ & $\begin{array}{l}1.75 \\
(0.15)\end{array}$ & $\begin{array}{l}0.96 \\
(0.09)\end{array}$ & $\begin{array}{l}9.75 \\
(0.31)\end{array}$ \\
\hline & M-FT & $\begin{array}{l}2.14 \\
(0.19)\end{array}$ & $\begin{array}{l}1.59 \\
(0.14)\end{array}$ & $\underset{(0.64)}{\mathbf{8 0 . 5 8}}$ & $\begin{array}{l}0.56 \\
(0.12)\end{array}$ & $\begin{array}{l}1.16 \\
(0.18)\end{array}$ & $\begin{array}{l}3.07 \\
(0.23)\end{array}$ & $\begin{array}{l}10.91 \\
(0.40)\end{array}$ \\
\hline & HNM-PT & $\begin{array}{l}4.35 \\
(0.42)\end{array}$ & $\begin{array}{l}0.58 \\
(0.12)\end{array}$ & $\begin{array}{l}0.77 \\
(0.27)\end{array}$ & $\underset{(1.03)}{\mathbf{8 2 . 0 2}}$ & $\begin{array}{l}1.87 \\
(0.24)\end{array}$ & $\begin{array}{l}1.93 \\
(0.26)\end{array}$ & $\begin{array}{l}8.48 \\
(0.83)\end{array}$ \\
\hline & LNM-PT & $\begin{array}{l}1.55 \\
(0.24)\end{array}$ & $\begin{array}{l}2.56 \\
(0.26)\end{array}$ & $\begin{array}{l}0.85 \\
(0.15)\end{array}$ & $\begin{array}{l}1.09 \\
(0.17)\end{array}$ & $\underset{(1.20)}{\mathbf{8 0 . 9 0}}$ & $\begin{array}{l}3.40 \\
(0.32)\end{array}$ & $\begin{array}{l}9.66 \\
(0.80)\end{array}$ \\
\hline & M-PT & $\begin{array}{l}1.10 \\
(0.14)\end{array}$ & $\begin{array}{l}1.17 \\
(0.11)\end{array}$ & $\begin{array}{l}2.35 \\
(0.19)\end{array}$ & $\begin{array}{l}1.27 \\
(0.18)\end{array}$ & $\begin{array}{l}3.26 \\
(0.27)\end{array}$ & $\underset{(0.66)}{\mathbf{8 1 . 1 3}}$ & $\begin{array}{l}9.73 \\
(0.44)\end{array}$ \\
\hline & N-EMP & $\begin{array}{l}2.23 \\
(0.12) \\
\end{array}$ & $\begin{array}{l}2.22 \\
(0.12) \\
\end{array}$ & $\begin{array}{l}1.83 \\
(0.14) \\
\end{array}$ & $\begin{array}{l}2.25 \\
(0.13) \\
\end{array}$ & $\begin{array}{r}4.60 \\
(0.20) \\
\end{array}$ & $\begin{array}{l}5.97 \\
(0.23) \\
\end{array}$ & $\begin{array}{c}\mathbf{8 0 . 9 1} \\
(0.31)\end{array}$ \\
\hline \multicolumn{2}{|l|}{ 1984-1992 } & \multicolumn{7}{|c|}{\begin{tabular}{|c} 
STATE IN YEAR $t+1$ \\
HNM-FT LNM-FT M-FT HNM-PT HNM-PT M-PT N-EMP
\end{tabular}} \\
\hline \multirow{7}{*}{ STATE IN YEAR $t$} & HNM-FT & $\begin{array}{l}\mathbf{9 3 . 9 3} \\
(0.42)\end{array}$ & $\begin{array}{l}0.80 \\
(0.08)\end{array}$ & $\begin{array}{l}0.56 \\
(0.09)\end{array}$ & $\begin{array}{l}1.59 \\
(0.16)\end{array}$ & $\begin{array}{l}0.40 \\
(0.08)\end{array}$ & $\begin{array}{l}0.40 \\
(0.07)\end{array}$ & $\begin{array}{l}2.32 \\
(0.20)\end{array}$ \\
\hline & LNM-FT & $\begin{array}{l}1.26 \\
(0.12)\end{array}$ & $\begin{array}{l}\mathbf{9 2 . 7 4} \\
(0.35)\end{array}$ & $\begin{array}{l}0.58 \\
(0.08)\end{array}$ & $\begin{array}{l}0.27 \\
(0.05)\end{array}$ & $\begin{array}{l}1.61 \\
(0.13)\end{array}$ & $\begin{array}{l}0.62 \\
(0.07)\end{array}$ & $\begin{array}{l}2.90 \\
(0.18)\end{array}$ \\
\hline & M-FT & $\begin{array}{l}1.39 \\
(0.16)\end{array}$ & $\begin{array}{l}1.08 \\
(0.15)\end{array}$ & $\underset{(0.68)}{\mathbf{9 0 . 3 9}}$ & $\begin{array}{l}0.40 \\
(0.10)\end{array}$ & $\begin{array}{l}1.07 \\
(0.18)\end{array}$ & $\begin{array}{l}2.27 \\
(0.22)\end{array}$ & $\begin{array}{l}3.40 \\
(0.25)\end{array}$ \\
\hline & HNM-PT & $\begin{array}{l}3.68 \\
(0.43)\end{array}$ & $\begin{array}{l}0.45 \\
(0.09)\end{array}$ & $\begin{array}{l}0.61 \\
(0.22)\end{array}$ & $\begin{array}{l}\mathbf{8 9 . 6 0} \\
(0.66)\end{array}$ & $\begin{array}{l}1.61 \\
(0.24)\end{array}$ & $\begin{array}{l}1.27 \\
(0.16)\end{array}$ & $\begin{array}{l}2.78 \\
(0.32)\end{array}$ \\
\hline & LNM-PT & $\begin{array}{l}1.39 \\
(0.20)\end{array}$ & $\begin{array}{l}2.68 \\
(0.24)\end{array}$ & $\begin{array}{l}0.81 \\
(0.15)\end{array}$ & $\begin{array}{l}0.92 \\
(0.14)\end{array}$ & $\underset{(0.80)}{\mathbf{8 8 . 2 1}}$ & $\begin{array}{l}2.57 \\
(0.25)\end{array}$ & $\begin{array}{l}3.42 \\
(0.34)\end{array}$ \\
\hline & M-PT & $\begin{array}{l}0.96 \\
(0.12)\end{array}$ & $\begin{array}{l}1.09 \\
(0.12)\end{array}$ & $\begin{array}{l}2.29 \\
(0.24)\end{array}$ & $\begin{array}{l}0.97 \\
(0.14)\end{array}$ & $\begin{array}{l}3.02 \\
(0.25)\end{array}$ & $\underset{(0.56)}{\mathbf{8 8 . 3 7}}$ & $\begin{array}{l}3.30 \\
(0.21)\end{array}$ \\
\hline & N-EMP & $\begin{array}{l}1.85 \\
(0.12) \\
\end{array}$ & $\begin{array}{l}1.82 \\
(0.16) \\
\end{array}$ & $\begin{array}{l}1.65 \\
(0.17) \\
\end{array}$ & $\begin{array}{l}1.98 \\
(0.14) \\
\end{array}$ & $\begin{array}{l}4.51 \\
(0.25) \\
\end{array}$ & $\begin{array}{l}4.61 \\
(0.22) \\
\end{array}$ & $\begin{array}{c}\mathbf{8 3 . 5 8} \\
(0.47)\end{array}$ \\
\hline
\end{tabular}

Table 4: Estimated one year transition matrices for the years 1975-1983, 1984-1992 and 1993-1999. All figures are in percentage terms. Standard errors in parenthesis. 


\begin{tabular}{|c|c|c|c|c|c|c|c|}
\hline AGE (YEARS) & HNM-FT & LNM-FT & M-FT & HNM-PT & LNM-PT & $\mathrm{M}-\mathrm{PT}$ & N-NEMP \\
\hline \multirow{2}{*}{16} & 4.74 & 48.48 & 29.54 & 0.21 & 1.06 & 0.96 & 15.01 \\
\hline & {$[5.32]$} & {$[49.08]$} & {$[28.52]$} & {$[0.29]$} & {$[1.15]$} & {$[1.12]$} & {$[14.52]$} \\
\hline \multirow{2}{*}{17} & 6.00 & 50.73 & 27.07 & 0.33 & 1.22 & 1.41 & 13.26 \\
\hline & {$[6.97]$} & {$[49.30]$} & {$[27.74]$} & {$[0.35]$} & {$[1.21]$} & [1.69] & {$[12.74]$} \\
\hline \multirow{2}{*}{18} & 10.01 & 46.76 & 23.22 & 0.49 & 1.66 & 2.33 & 15.54 \\
\hline & {$[9.53]$} & {$[46.05]$} & {$[23.50]$} & {$[0.52]$} & {$[1.41]$} & [1.98] & {$[17.02]$} \\
\hline \multirow{2}{*}{19} & 11.67 & 45.22 & 21.95 & 0.76 & 2.00 & 2.55 & 15.86 \\
\hline & {$[11.21]$} & {$[44.43]$} & {$[22.52]$} & {$[0.66]$} & {$[1.60]$} & {$[2.52]$} & {$[17.05]$} \\
\hline \multirow{2}{*}{20} & 12.56 & 42.06 & 20.83 & 0.94 & 2.11 & 3.28 & 18.22 \\
\hline & [12.43] & {$[41.45]$} & {$[20.71]$} & {$[0.85]$} & {$[1.85]$} & {$[3.03]$} & [19.68] \\
\hline \multirow{2}{*}{21} & 14.73 & 37.48 & 17.75 & 1.04 & 2.04 & 3.52 & 23.44 \\
\hline & [14.04] & {$[37.04]$} & {$[18.26]$} & {$[1.16]$} & {$[2.21]$} & [3.53] & {$[23.76]$} \\
\hline \multirow{2}{*}{22} & 16.42 & 34.44 & 15.51 & 1.81 & 2.41 & 3.77 & 25.63 \\
\hline & {$[15.46]$} & {$[33.12]$} & [16.20] & {$[1.55]$} & {$[2.67]$} & {$[4.15]$} & {$[26.83]$} \\
\hline \multirow{2}{*}{23} & 17.27 & 29.63 & 13.78 & 2.01 & 2.81 & 4.35 & 30.16 \\
\hline & [16.44] & [29.63] & [14.41] & {$[2.01]$} & {$[3.23]$} & {$[4.88]$} & {$[29.40]$} \\
\hline \multirow{2}{*}{24} & 17.78 & 27.61 & 12.91 & 2.24 & 3.31 & 5.23 & 30.92 \\
\hline & {$[16.80]$} & {$[26.74]$} & [12.94] & {$[2.48]$} & {$[3.93]$} & {$[5.78]$} & [31.33] \\
\hline \multirow{2}{*}{25} & 18.12 & 24.46 & 11.42 & 2.71 & 3.95 & 6.70 & 32.64 \\
\hline & {$[16.76]$} & [24.08] & [11.66] & {$[3.01]$} & {$[4.74]$} & {$[6.78]$} & {$[32.97]$} \\
\hline \multirow{2}{*}{26} & 17.01 & 22.58 & 10.52 & 3.21 & 4.42 & 7.55 & 34.70 \\
\hline & {$[16.45]$} & [21.65] & {$[10.57]$} & {$[3.57]$} & {$[5.67]$} & {$[7.90]$} & [34.18] \\
\hline \multirow{2}{*}{27} & 15.85 & 20.06 & 10.02 & 4.01 & 5.75 & 9.07 & 35.24 \\
\hline & [15.97] & [19.43] & [9.68] & {$[4.19]$} & {$[6.72]$} & [9.11] & {$[34.92]$} \\
\hline \multirow{2}{*}{28} & 15.88 & 17.44 & 9.93 & 4.54 & 6.95 & 10.52 & 34.74 \\
\hline & {$[15.44]$} & {$[17.61]$} & {$[9.00]$} & {$[4.83]$} & {$[7.77]$} & {$[10.28]$} & {$[35.07]$} \\
\hline \multirow{2}{*}{29} & 15.41 & 16.59 & 8.96 & 5.69 & 8.46 & 11.55 & 33.35 \\
\hline & {$[14.87]$} & {$[16.11]$} & {$[8.46]$} & {$[5.50]$} & {$[8.86]$} & {$[11.42]$} & {$[34.78]$} \\
\hline \multirow{2}{*}{30} & 15.26 & 15.47 & 8.72 & 6.22 & 10.05 & 12.29 & 32.00 \\
\hline & {$[14.46]$} & {$[14.91]$} & {$[8.07]$} & {$[6.15]$} & {$[9.92]$} & {$[12.47]$} & {$[34.02]$} \\
\hline \multirow{2}{*}{31} & 14.14 & 14.73 & 8.54 & 7.10 & 11.37 & 13.29 & 30.82 \\
\hline & {$[14.17]$} & {$[14.02]$} & {$[7.81]$} & {$[6.76]$} & [10.99] & [13.48] & {$[32.76]$} \\
\hline \multirow{2}{*}{32} & 14.11 & 14.20 & 8.10 & 8.10 & 12.43 & 14.02 & 29.02 \\
\hline & [14.01] & [13.43] & {$[7.70]$} & {$[7.31]$} & [11.99] & [14.32] & {$[31.24]$} \\
\hline \multirow{2}{*}{33} & 14.08 & 13.67 & 7.51 & 8.19 & 12.79 & 14.73 & 29.02 \\
\hline & [13.98] & {$[13.02]$} & {$[7.67]$} & {$[7.80]$} & [12.87] & [14.98] & [29.68] \\
\hline \multirow{2}{*}{34} & 14.17 & 13.76 & 7.87 & 8.63 & 14.08 & 14.53 & 26.96 \\
\hline & [14.18] & [12.90] & {$[7.76]$} & {$[8.20]$} & {$[13.62]$} & {$[15.44]$} & {$[27.89]$} \\
\hline \multirow{2}{*}{35} & 14.85 & 13.76 & 8.04 & 8.81 & 14.11 & 14.88 & 25.55 \\
\hline & [14.54] & [13.01] & [7.95] & {$[8.51]$} & {$[14.26]$} & {$[15.77]$} & {$[25.97]$} \\
\hline 36 & 15.26 & 13.73 & 8.28 & 8.78 & 14.53 & 15.14 & 24.28 \\
\hline 36 & {$[15.01]$} & [13.24] & {$[8.21]$} & {$[8.74]$} & {$[14.74]$} & {$[15.97]$} & [24.09] \\
\hline & 15.82 & 13.91 & 8.49 & 8.66 & 14.67 & 15.50 & 22.95 \\
\hline 37 & {$[15.55]$} & {$[13.54]$} & {$[8.53]$} & {$[8.92]$} & {$[15.11]$} & {$[16.07]$} & {$[22.29]$} \\
\hline & 16.47 & 14.26 & 9.10 & 8.90 & 14.79 & 15.29 & 21.18 \\
\hline 38 & {$[16.16]$} & [13.95] & {$[8.90]$} & {$[9.03]$} & [15.33] & {$[16.02]$} & {$[20.62]$} \\
\hline 39 & 17.38 & 14.17 & 9.40 & 9.05 & 15.03 & 15.38 & 19.59 \\
\hline 39 & [16.78] & {$[14.40]$} & {$[9.28]$} & {$[9.08]$} & {$[15.41]$} & {$[15.89]$} & {$[19.16]$} \\
\hline & 17.65 & 14.70 & 9.69 & 9.34 & 15.03 & 15.23 & 18.36 \\
\hline 40 & {$[17.41]$} & {$[14.91]$} & [9.71] & [9.09] & [15.39] & {$[15.70]$} & {$[17.79]$} \\
\hline
\end{tabular}

Table 5: Observed and simulated (in square brackets) percentages of women in each labor market state between ages 16 and 40 years. 


\section{Appendix III: Model without Persistent Unobserved Heterogeneity}

\begin{tabular}{|c|c|c|c|c|c|c|c|}
\hline & 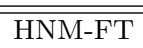 & "LNM-FT & M-FT & HNM-PT & LNM-PT & M-PT & N-EMP \\
\hline $\mathrm{HNM} \mathrm{FT}_{t-1}$ & $\begin{array}{l}5.50^{* *} \\
(0.24)\end{array}$ & $\stackrel{1}{(0.17)}^{* *}$ & $\begin{array}{l}1.38^{* *} \\
(0.19)\end{array}$ & $\stackrel{1.26}{(0.19)}^{* *}$ & $\begin{array}{r}-0.03 \\
(0.24)\end{array}$ & $\begin{array}{l}0.24 \\
(0.21)\end{array}$ & \\
\hline $\mathrm{LNM}_{-\mathrm{FT}_{t-1}}$ & $\begin{array}{l}1.57^{* *} \\
(0.16)\end{array}$ & $\begin{array}{l}3.40^{* *} \\
(0.16)\end{array}$ & $e_{(0.15)}{ }^{* *}$ & $\begin{array}{l}0.36 \\
(0.24)\end{array}$ & $\begin{array}{l}0.56 \text { ** } \\
(0.17)\end{array}$ & $\begin{array}{l}0.20 \\
(0.18)\end{array}$ & \\
\hline${\mathrm{M}-\mathrm{FT}_{t-1}}$ & $\left.{ }_{(0.17)}^{1.39}\right)^{* *}$ & $\left.\operatorname{lol}_{(0.15)}\right)^{* *}$ & $\begin{array}{l}3.48^{* *} \\
(0.18)\end{array}$ & $\begin{array}{l}0.39 \\
(0.27)\end{array}$ & $\begin{array}{l}0.35 \\
(0.21)\end{array}$ & $\begin{array}{l}0.98^{* *} \\
(0.17)^{*}\end{array}$ & \\
\hline $\mathrm{HNM} \mathrm{PT}_{t-1}$ & ${ }_{(0.22)}^{1.80 * *}$ & $\begin{array}{l}0.25 \\
(0.33)\end{array}$ & $\begin{array}{l}0.89^{* *} \\
(0.33)\end{array}$ & $\begin{array}{l}8.38^{* *} \\
(0.58)\end{array}$ & $\begin{array}{l}0.87^{* *} \\
(0.25)\end{array}$ & $\begin{array}{l}0.77^{* *} \\
(0.25)\end{array}$ & \\
\hline $\mathrm{LNM} \mathrm{PT}_{t-1}$ & $\stackrel{1.10}{(0.22)}^{* *}$ & $\stackrel{1.41}{ }_{(0.19)}^{* *}$ & $\begin{array}{l}0.88^{* *} \\
(0.25)\end{array}$ & $\begin{array}{l}0.83^{* *} \\
(0.24)\end{array}$ & $\begin{array}{l}6.68^{* *} \\
(0.32)\end{array}$ & $\begin{array}{l}1.05 \\
(0.19)\end{array}$ & \\
\hline $\mathrm{M}_{-\mathrm{PT}_{t-1}}$ & $\begin{array}{l}0.855^{* *} \\
(0.21)\end{array}$ & $\begin{array}{l}0.70 * * \\
(0.20)\end{array}$ & $\begin{array}{l}1.65 \\
(0.18)\end{array}$ & $\underbrace{1.20 *}_{(0.23)}$ & $\begin{array}{l}1.17^{* *} \\
(0.19)\end{array}$ & $\begin{array}{l}5.17^{* *} \\
(0.28)\end{array}$ & \\
\hline OWN STATE $t-1 \times$ TIME & $\begin{array}{l}0.15^{* *} \\
(0.03)\end{array}$ & $\begin{array}{l}0.13^{* *} \\
(0.02)\end{array}$ & $\begin{array}{l}0.17^{* *} \\
(0.03)\end{array}$ & $\begin{array}{l}-0.44^{* *} \\
(0.07)\end{array}$ & $\begin{array}{l}-0.30^{* *} \\
(0.04)\end{array}$ & $\begin{array}{l}-0.18^{* *} \\
(0.04)\end{array}$ & $\begin{array}{l}-0.05^{* *} \\
(0.02)\end{array}$ \\
\hline OWN STATE $_{t-1} \times \operatorname{TIME}^{2} / 100$ & $\stackrel{0}{0.66}_{(0.12)}^{* *}$ & $\begin{array}{l}-0.222^{* *} \\
(0.09)\end{array}$ & $\begin{array}{l}0.39^{* *} \\
(0.11)\end{array}$ & $\begin{array}{l}0.26 \\
(0.23)\end{array}$ & $\begin{array}{l}0.83^{* *} \\
(0.14)\end{array}$ & $\begin{array}{l}0.66 \\
(0.12)\end{array}$ & $\begin{array}{l}0.50 \\
(0.08)\end{array}$ \\
\hline EXP-HNM-FT & $\begin{array}{l}0.16^{* *} \\
(0.01)\end{array}$ & $\begin{array}{l}0.04 \\
(0.01)\end{array}$ & $\begin{array}{l}0.03^{* *} \\
(0.01)\end{array}$ & $\begin{array}{l}0.14 \\
(0.01)\end{array}$ & $\begin{array}{l}0.03 \\
(0.01)\end{array}$ & $\begin{array}{l}0.00 \\
(0.01)\end{array}$ & \\
\hline EXP-LNM-FT & $\begin{array}{l}0.07^{* *} \\
(0.01)\end{array}$ & $\begin{array}{l}0.14 \\
(0.01)\end{array}$ & $\begin{array}{l}0.01 \\
(0.01)\end{array}$ & $\begin{array}{l}0.02 \\
(0.01)\end{array}$ & $\begin{array}{l}0.10^{* *} \\
(0.01)\end{array}$ & $\begin{array}{l}0.03^{* *} \\
(0.01)\end{array}$ & \\
\hline EXP-M-FT & $\begin{array}{l}0.066^{* *} \\
(0.01)\end{array}$ & $\begin{array}{l}0.05 \text { ** } \\
(0.01)\end{array}$ & $\begin{array}{l}0.09 \\
(0.01)\end{array}$ & $\begin{array}{l}0.03 \\
(0.02)\end{array}$ & $\begin{array}{l}0.05 \\
(0.01)\end{array}$ & $\begin{array}{l}0.05 \\
(0.01)\end{array}$ & \\
\hline EXP-HNM-PT & $\begin{array}{l}0.19^{* *} \\
(0.02)\end{array}$ & $\begin{array}{l}0.10 \\
(0.04)\end{array}$ & $\begin{array}{l}0.04 \\
(0.04)\end{array}$ & $\begin{array}{l}0.222^{* *} \\
(0.02)\end{array}$ & $\begin{array}{l}0.06 \\
(0.03)\end{array}$ & $\begin{array}{l}0.02 \\
(0.03)\end{array}$ & \\
\hline EXP-LNM-PT & $\begin{array}{l}0.11 \\
(0.02)\end{array}$ & $\begin{array}{l}0.15^{* *} \\
(0.02)\end{array}$ & $\begin{array}{l}0.05 \\
(0.03)\end{array}$ & $\begin{array}{l}0.11 \\
(0.02)\end{array}$ & $\begin{array}{l}0.16 \\
(0.01)\end{array}$ & $\begin{array}{l}0.05 \text { ** } \\
(0.02)\end{array}$ & \\
\hline EXP-M-PT & $\begin{array}{l}0.10^{* *} \\
(0.02)\end{array}$ & $\begin{array}{l}0.13 \\
(0.02)\end{array}$ & $\begin{array}{l}0.09 \text { ** } \\
(0.02)\end{array}$ & $\begin{array}{l}0.05 * * \\
(0.02)\end{array}$ & $\begin{array}{l}0.08 * * \\
(0.01)\end{array}$ & $\begin{array}{l}0.10^{* *} \\
(0.01)\end{array}$ & \\
\hline O LEVELS & $\begin{array}{l}0.30 \\
(0.05)\end{array}$ & $\begin{array}{l}0.29 * * \\
(0.04)\end{array}$ & $\begin{array}{c}-0.11 * \\
(0.05)\end{array}$ & $\begin{array}{l}0.37 * * \\
(0.08)\end{array}$ & $\begin{array}{l}0.29 \\
(0.05)\end{array}$ & $\begin{array}{r}-0.05 \\
(0.05)\end{array}$ & \\
\hline A LEVELS & $\begin{array}{l}0.477^{* *} \\
(0.09)\end{array}$ & $\begin{array}{l}0.44 * * \\
(0.08)\end{array}$ & $\begin{array}{c}-0.40^{* *} \\
(0.10)\end{array}$ & $\begin{array}{l}0.36 \text { ** } \\
(0.13)\end{array}$ & $\begin{array}{l}0.34 \\
(0.11)\end{array}$ & $\begin{array}{l}-0.27 * \\
(0.12)\end{array}$ & \\
\hline DEGREE & $\begin{array}{l}0.57^{* *} \\
(0.12)\end{array}$ & $\begin{array}{l}0.27 \\
(0.14)\end{array}$ & $\begin{array}{r}-0.10 \\
(0.16)\end{array}$ & $\begin{array}{l}0.39 * \\
(0.18)\end{array}$ & $\begin{array}{l}0.25 \\
(0.18)\end{array}$ & $\begin{array}{r}-0.32 \\
(0.19)\end{array}$ & \\
\hline FATHER'S SOCIAL CLASS & $\begin{array}{r}-0.06 \\
(0.05)\end{array}$ & $\begin{array}{r}-0.06 \\
(0.04)\end{array}$ & $\begin{array}{c}-0.18^{* *} \\
(0.05)\end{array}$ & $\begin{array}{l}0.19 \\
(0.07)\end{array}$ & $\begin{array}{r}-0.02 \\
(0.05)\end{array}$ & $\begin{array}{r}-0.04 \\
(0.05)\end{array}$ & \\
\hline CHILD04 & $\begin{array}{c}-1.41 \\
(0.18)\end{array}$ & $\begin{array}{c}-1.58^{* *} \\
(0.14)\end{array}$ & $\begin{array}{c}-1.43^{* *} \\
(0.14)\end{array}$ & $\begin{array}{r}-0.21 \\
(0.28)\end{array}$ & $\begin{array}{r}-0.24 \\
(0.19)\end{array}$ & $\begin{array}{c}-0.25^{*} \\
(0.13)\end{array}$ & \\
\hline CHILD511 & $\begin{array}{c}-0.48^{* *} \\
(0.15)\end{array}$ & $\begin{array}{c}-0.34^{* *} \\
(0.11)\end{array}$ & $\begin{array}{c}-0.39^{* *} \\
(0.11)\end{array}$ & $\begin{array}{r}-0.01 \\
(0.20)\end{array}$ & $\begin{array}{r}-0.02 \\
(0.11)\end{array}$ & $\begin{array}{l}0.22 \\
(0.09)\end{array}$ * & \\
\hline CHILD1215 & $\begin{array}{l}0.18 \\
(0.21)\end{array}$ & $\begin{array}{r}-0.10 \\
(0.22)\end{array}$ & $\begin{array}{r}-0.05 \\
(0.19)\end{array}$ & $\begin{array}{c}-0.32 \\
(0.63)\end{array}$ & $\begin{array}{l}0.15 \\
(0.19)\end{array}$ & $\begin{array}{l}0.17 \\
(0.14)\end{array}$ & \\
\hline COHABIT & $\begin{array}{c}-0.80^{* *} \\
(0.07)\end{array}$ & $\begin{array}{c}-0.67^{* *} \\
(0.06)\end{array}$ & $\begin{array}{c}-0.77^{* *} \\
(0.07)\end{array}$ & $\begin{array}{c}-0.18^{*} \\
(0.13)\end{array}$ & $\begin{array}{r}-0.10 \\
(0.11)\end{array}$ & $\begin{array}{c}-0.28^{* *} \\
(0.09)\end{array}$ & \\
\hline COHABIT $\times$ CHILD04 & $\begin{array}{l}0.23 \\
(0.18)\end{array}$ & $\begin{array}{r}-0.04 \\
(0.14)\end{array}$ & ${ }_{(0.15)}^{0.54}$ & $\begin{array}{c}0.04 \\
(0.28)\end{array}$ & $\begin{array}{c}0.02 \\
(0.19)\end{array}$ & $\begin{array}{c}0.14 \\
(0.13)\end{array}$ & \\
\hline COHABIT $\times$ CHILD 511 & $\begin{array}{l}0.66^{* *} \\
(0.15)\end{array}$ & $\begin{array}{l}0.43 \\
(0.11)\end{array}$ & $\begin{array}{l}0.56 \\
(0.12)\end{array}$ & $\begin{array}{l}0.28 \\
(0.19)\end{array}$ & $\begin{array}{l}0.39 \\
(0.11)\end{array}$ & $\begin{array}{l}0.24 \\
(0.09)\end{array}$ & \\
\hline COHABIT $\times$ CHILD1215 & $\begin{array}{c}0.29 \\
(0.22)\end{array}$ & $\begin{array}{l}0.35 \\
(0.23)\end{array}$ & $\begin{array}{c}0.35 \\
(0.20)\end{array}$ & $\begin{array}{c}0.59 \\
(0.63)\end{array}$ & $\begin{array}{c}0.17 \\
(0.19)\end{array}$ & $\begin{array}{l}0.12 \\
(0.15)\end{array}$ & \\
\hline \# OF CHILDREN BY 40 & $\begin{array}{c}-0.19^{* *} \\
(0.03)\end{array}$ & $\begin{array}{c}-0.21 \\
(0.02)\end{array}$ & $\begin{array}{c}-0.13^{* *} \\
(0.03)\end{array}$ & $\begin{array}{r}-0.07 \\
(0.05)\end{array}$ & $\begin{array}{c}-0.27^{* *} \\
(0.04)\end{array}$ & $\begin{array}{c}-0.21^{* *} \\
(0.03)\end{array}$ & \\
\hline AGE AT FIRST CHILD/10 & $\begin{array}{l}0.06 \\
(0.02)\end{array}$ & $\begin{array}{l}0.06 \\
(0.02)\end{array}$ & $\begin{array}{r}-0.01 \\
(0.02)\end{array}$ & $\begin{array}{l}0.12 \\
(0.04)\end{array}$ ** & $\begin{array}{l}0.15^{* *} \\
(0.03)\end{array}$ & $\begin{array}{l}0.05 \\
(0.03)\end{array}$ & \\
\hline LOG (PARTNERS PAY/100) & $\begin{array}{r}-0.04 \\
(0.03)\end{array}$ & $\begin{array}{r}-0.03 \\
(0.03)\end{array}$ & $\begin{array}{l}-0.08^{*} \\
(0.04)\end{array}$ & $\begin{array}{r}-0.02 \\
(0.04)\end{array}$ & $\begin{array}{r}-0.04 \\
(0.03)\end{array}$ & $\begin{array}{c}-0.09 * * \\
(0.03)\end{array}$ & \\
\hline INTERCEPT & $\begin{array}{c}-1.83^{* *} \\
(0.16) \\
\end{array}$ & $\begin{array}{r}0.14 \\
(0.12) \\
\end{array}$ & $\begin{array}{r}-0.13 \\
(0.14) \\
\end{array}$ & $\begin{array}{c}-5.511^{* *} \\
(0.33)\end{array}$ & $\begin{array}{c}-3.87^{* *} \\
(0.24) \\
\end{array}$ & $\begin{array}{c}-2.42^{* *} \\
(0.19) \\
\end{array}$ & \\
\hline Log Likelihood & -50010.80 & Pseudo $\mathrm{R}^{2}$ & $65.74 \%$ & BIC & 102483.61 & & \\
\hline
\end{tabular}

Table 6: Parameter estimates for multinomial logit model of labor market outcomes without persistent unobserved heterogeneity. The model also includes time trends, year of entry trends, and controls for first year in the labor market interacted with level of qualifications (see Table 7). Standard errors in parenthesis. ${ }^{*}$ indicates significance at the $5 \%$ level and ${ }^{* *}$ indicates significance at the $1 \%$ level. 


\begin{tabular}{ccccccc}
\hline \hline & HNM-FT & LNM-FT & M-FT & HNM-PT & LNM-PT & M-PT \\
\hline YEAR OF ENTRY TREND & $-0.38^{* *}$ & -0.05 & $-0.08^{*}$ & $-0.23^{* *}$ & 0.05 & $0.12^{*}$ \\
& $(0.03)$ & $(0.03)$ & $(0.04)$ & $(0.05)$ & $(0.05)$ & $(0.05)$ \\
YEAR OF ENTRY TREND $/ 100$ & $0.80^{* *}$ & 0.01 & $0.16^{* *}$ & $0.31^{*}$ & 0.14 & -0.22 \\
& $(0.10)$ & $(0.11)$ & $(0.05)$ & $(0.15)$ & $(0.15)$ & $(0.15)$ \\
TIME & $0.24^{* *}$ & $-0.28^{* *}$ & $-0.21^{* *}$ & $0.37^{* *}$ & 0.02 & $-0.11^{*}$ \\
& $(0.03)$ & $(0.04)$ & $(0.04)$ & $(0.06)$ & $(0.06)$ & $(0.05)$ \\
TIME ${ }^{2} / 100$ & $0.22^{*}$ & $0.84^{* *}$ & $0.79^{* *}$ & $-0.61^{* *}$ & 0.04 & $0.30^{*}$ \\
& $(0.12)$ & $(0.13)$ & $(0.16)$ & $(0.17)$ & $(0.18)$ & $(0.16)$ \\
ENTRY $\times$ NO QUALIFICATIONS & $1.15^{* *}$ & $1.67^{* *}$ & $1.80^{* *}$ & 0.94 & $1.42^{* *}$ & 0.32 \\
& $(0.20)$ & $(0.13)$ & $(0.14)$ & $(0.69)$ & $(0.35)$ & $(0.31)$ \\
ENTRY $\times$ O LEVELS & $0.94^{* *}$ & $1.42^{* *}$ & $0.58^{* *}$ & 0.53 & $1.84 * *$ & -0.35 \\
& $(0.15)$ & $(0.11)$ & $(0.14)$ & $(0.46)$ & $(0.31)$ & $(0.33)$ \\
ENTRY $\times$ DEGREE OR A LEVELS & 0.16 & -0.01 & -0.11 & 0.02 & 0.21 & $-0.255^{* *}$ \\
& $(0.12)$ & $(0.14)$ & $(0.19)$ & $(0.35)$ & $(0.34)$ & $(0.42)$ \\
\hline
\end{tabular}

Table 7: Additions controls included in multinomial logit model of labor market outcomes without persistent unobserved heterogeneity. Standard errors in parenthesis. * indicates significance at the $5 \%$ level and ${ }^{* *}$ indicates significance at the $1 \%$ level.

\section{Appendix IV: Distribution of the Random Effect}

This appendix explores the implications of varying the number of mass points in the distribution of the random effect $\alpha_{i}$. Table 8 summarizes the results of multinomial logit models of labor market outcomes with persistent unobserved heterogeneity represented by two, three and four mass points. Each extra mass point adds two parameters: one for the location of the extra mass point and one for the probability attached to the extra mass point. The log likelihood values and Pseudo $\mathrm{R}^{2}$ values are increasing in the number of mass points, as must be the case. The Bayesian Information Criterion is lowest for the model with persistent unobserved heterogeneity represented by three mass points. Thus, based on this model selection criterion, the model with three mass points is the preferred model.

\begin{tabular}{cccc}
\hline \hline & \multicolumn{3}{c}{ NUMBER OF MASS POINTS } \\
\cline { 2 - 4 } & TWO & THREE & FOUR \\
\cline { 2 - 4 } Log Likelihood & -49871.99 & -49821.66 & -49811.01 \\
\# of Parameters & 225 & 227 & 229 \\
McFadden's Pseudo R & 65.84 & 65.87 & 65.88 \\
BIC & 102285.03 & 102206.96 & 102208.24 \\
\hline
\end{tabular}

Table 8: Summary of results multinomial logit models of labor market outcomes with persistent unobserved heterogeneity represented by two, three and four mass points. 